\title{
Observations of speciated isoprene nitrates in Beijing: implications for isoprene chemistry
}

\author{
Claire E. Reeves ${ }^{1}$, Graham P. Mills ${ }^{1}$, Lisa K. Whalley ${ }^{2}$, W. Joe F. Acton ${ }^{3}$, William J. Bloss ${ }^{4}$, Leigh R. Crilley ${ }^{4, \text { a }}$, \\ Sue Grimmond $^{5}$, Dwayne E. Heard ${ }^{6}$, C. Nicholas Hewitt ${ }^{3}$, James R. Hopkins ${ }^{7}$, Simone Kotthaus ${ }^{6,8}$, \\ Louisa J. Kramer ${ }^{4}$, Roderic L. Jones ${ }^{9}$, James D. Lee ${ }^{7}$, Yanhui Liu ${ }^{1}$, Bin Ouyang ${ }^{9}$, Eloise Slater ${ }^{6}$, Freya Squires ${ }^{10}$, \\ Xinming Wang ${ }^{11}$, Robert Woodward-Massey ${ }^{12}$, and Chunxiang Ye $^{12}$ \\ ${ }^{1}$ Centre for Ocean and Atmospheric Sciences, School of Environmental Sciences, University of East Anglia, Norwich, UK \\ ${ }^{2}$ National Centre for Atmospheric Science, School of Chemistry, University of Leeds, Leeds, UK \\ ${ }^{3}$ Lancaster Environment Centre, Lancaster University, Lancaster, UK \\ ${ }^{4}$ School of Geography, Earth and Environmental Sciences, the University of Birmingham, Birmingham, UK \\ ${ }^{5}$ Department of Meteorology, University of Reading, Reading, UK \\ ${ }^{6}$ School of Chemistry, University of Leeds, Leeds, UK \\ ${ }^{7}$ National Centre for Atmospheric Science, Wolfson Atmospheric Chemistry Laboratories, \\ Department of Chemistry, University of York, York, UK \\ ${ }^{8}$ Institut Pierre Simon Laplace, École Polytechnique, Paris, France \\ ${ }^{9}$ Department of Chemistry, University of Cambridge, Cambridge, UK \\ ${ }^{10}$ Wolfson Atmospheric Chemistry Laboratories, Department of Chemistry, University of York, York, UK \\ ${ }^{11}$ Guangzhou Institute of Geochemistry, Chinese Academy of Sciences, Guangzhou, China \\ ${ }^{12}$ Beijing Innovation Center for Engineering Science and Advanced Technology, State Key Joint Laboratory for \\ Environmental Simulation and Pollution Control, Center for Environment and Health, College of Environmental \\ Sciences and Engineering, Peking University, Beijing, China \\ ${ }^{a}$ now at: Department of Chemistry, York University, Toronto, Canada
}

Correspondence: Claire E. Reeves (c.reeves@uea.ac.uk)

Received: 20 October 2019 - Discussion started: 27 January 2020

Revised: 8 January 2021 - Accepted: 5 March 2021 - Published: 27 April 2021

\begin{abstract}
Isoprene is the most important biogenic volatile organic compound in the atmosphere. Its calculated impact on ozone $\left(\mathrm{O}_{3}\right)$ is critically dependent on the model isoprene oxidation chemical scheme, in particular the way the isoprene-derived organic nitrates (IN) are treated. By combining gas chromatography with mass spectrometry, we have developed a system capable of separating and unambiguously measuring individual IN isomers. In this paper we use measurements from its first field deployment, which took place in Beijing as part of the Atmospheric Pollution and Human Health in a Chinese Megacity programme, to test understanding of the isoprene chemistry as simulated in the Master Chemical Mechanism (MCM) (v.3.3.1). Seven individual isoprene nitrates were identified and quantified during
\end{abstract}

the campaign: two $\beta$-hydroxy nitrates (IHN), four $\delta$-carbonyl nitrates (ICN), and propanone nitrate.

Our measurements show that in the summertime conditions experienced in Beijing the ratio of $\left(1-\mathrm{OH}, 2-\mathrm{ONO}_{2}\right)$ IHN to $\left(4-\mathrm{OH}, 3-\mathrm{ONO}_{2}\right)-\mathrm{IHN}$ (the numbers indicate the carbon atom in the isoprene chain to which the radical is added) increases at $\mathrm{NO}$ mixing ratios below $2 \mathrm{ppb}$. This provides observational field evidence of the redistribution of the peroxy radicals derived from $\mathrm{OH}$ oxidation of isoprene away from the kinetic ratio towards a new thermodynamic equilibrium consistent with box model calculations. The observed amounts of $\delta$-ICN demonstrate the importance of daytime addition of $\mathrm{NO}_{3}$ to isoprene in Beijing but suggest that the predominant source of the $\delta$-ICN in the model (reaction of NO with $\delta$-nitrooxy peroxy radicals) may be too large. Our 
speciated measurements of the four $\delta$-ICN exhibit a mean $\mathrm{C} 1$ : $\mathrm{C} 4$ isomer ratio of 1.4 and a mean trans : cis isomer ratio of 7 and provide insight into the isomeric distribution of the $\delta$-nitrooxy peroxy radicals. Together our measurements and model results indicate that propanone nitrate was formed from the $\mathrm{OH}$ oxidation of $\delta$-ICN both during the day and night, as well as from $\mathrm{NO}_{3}$ addition to propene at night.

This study demonstrates the value of speciated IN measurements in testing understanding of the isoprene degradation chemistry and shows how more extensive measurements would provide greater constraints. It highlights areas of the isoprene chemistry that warrant further study, in particular the impact of $\mathrm{NO}$ on the formation of the IHN and the $\mathrm{NO}_{3}$ initiated isoprene degradation chemistry, as well as the need for further laboratory studies on the formation and the losses of IN, in particular via photolysis of $\delta$-ICN and hydrolysis.

\section{Introduction}

Isoprene is the most important biogenic volatile organic compound (BVOC) in the atmosphere, with its emissions accounting for around $500 \mathrm{Tg} \mathrm{yr}^{-1}$, about half of the global biogenic non-methane VOC emissions (Guenther et al., 2012). It is emitted by vegetation primarily during the daytime as a function of temperature and solar radiation and is readily oxidised by the hydroxyl $(\mathrm{OH})$ and nitrate $\left(\mathrm{NO}_{3}\right)$ radicals and ozone $\left(\mathrm{O}_{3}\right)$. Through its degradation chemistry, isoprene impacts $\mathrm{O}_{3}$ and the formation of secondary organic aerosols (SOAs), which together impact the oxidising capacity of the atmosphere and radiative forcing. Global and regional model studies have shown that the calculated impact of isoprene on $\mathrm{O}_{3}$ is critically dependent on the model isoprene oxidation chemical scheme, in particular the way the isoprene-derived nitrates (IN) are treated (e.g. Emmerson and Evans, 2009; Fiore et al., 2005; Squire et al., 2015; von Kuhlman et al., 2004; Wu et al., 2007; Bates and Jacob, 2019; Schwantes et al., 2020). Much of the uncertainty in this chemistry is related to the yield and fate of $\mathrm{IN}$, in particular whether $\mathrm{NO}_{x}$ (nitrogen oxides) and radicals, which are tied up in the nitrates, are later recycled or lost from the atmosphere.

First-generation IN are formed following oxidation of isoprene by either $\mathrm{OH}$ or $\mathrm{NO}_{3}$ (Wennberg et al., 2018) (Fig. 1). On oxidation by $\mathrm{OH}$, peroxy radicals are formed, which when they react with nitric oxide (NO) can lead to the formation of hydroxy nitrates (IHN). These are dominated by $\beta$-IHN, but some $\delta$-IHN are also formed. Depending on the fate of the peroxy radicals formed following $\mathrm{NO}_{3}$ addition, a variety of IN can be produced: isoprene hydroperoxy nitrates (IPN), isoprene dinitrates (IDN), isoprene carbonyl nitrates (ICN), and IHN. While the fate of first-generation IN is poorly understood, much advancement in recent years has been made through new laboratory studies following the synthesis of some of the IN (Jacobs et al., 2014; Lee et al., 2014;

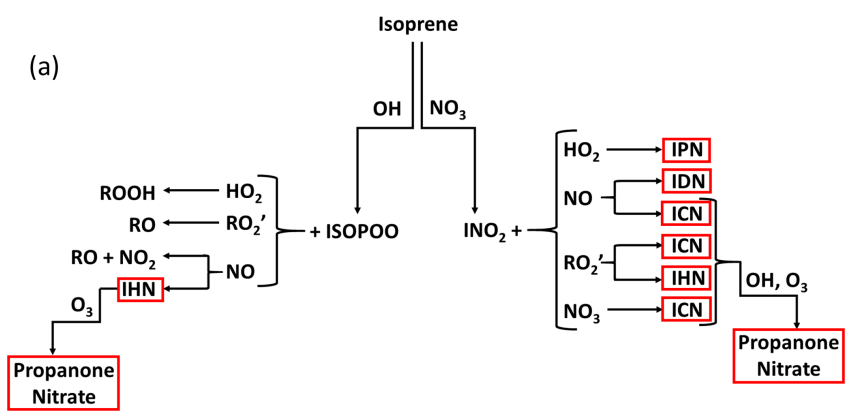

(b)

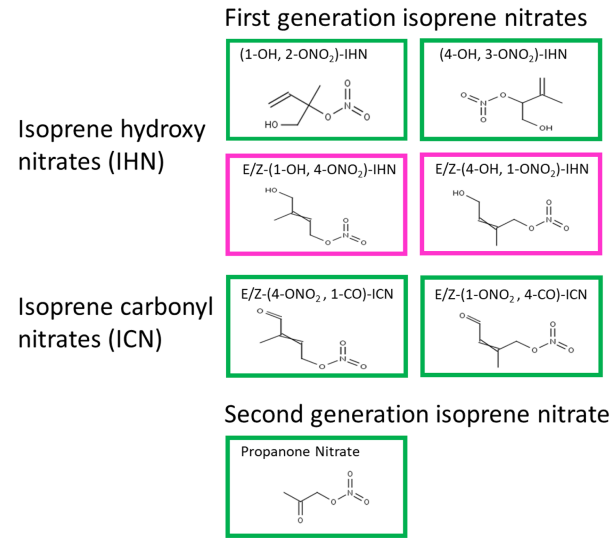

Figure 1. (a) Formation of IN (red boxes) from isoprene oxidation by $\mathrm{OH}$ and $\mathrm{NO}_{3}$ : isoprene hydroxy nitrates (IHN), isoprene hydroperoxy nitrates (IPN), isoprene dinitrates (IDN), isoprene carbonyl nitrates (ICN), and propanone nitrate. (b) The skeletal formula of the specific IN discussed in this paper. Box colours are as follows: green represents measured in Beijing, and pink represents measured by the analytical system previously in the laboratory but not discernible in Beijing.

Lockwood, et al., 2010; Teng et al., 2017; Xiong et al., 2016), but these are still limited to specific IN isomers (six IHN and one ICN), and reaction rate constants for others are based on extrapolation and structural activity relationships. The IN are lost via reaction with $\mathrm{OH}, \mathrm{O}_{3}$, and $\mathrm{NO}_{3}$ (Wennberg et al., 2018) and by photolysis (Xiong et al., 2016; Müller et al., 2014) and deposition (Nguyen et al., 2015) and have lifetimes of the order of a few hours. Reactions of the IHN and ICN with $\mathrm{OH}$ can lead to the formation of carbonyls and release of $\mathrm{NO}_{2}$, as well as the formation of shorter-chained nitrates such as methyl vinyl ketone nitrate, methacrolein nitrate, propanone nitrate (acetone nitrate), and ethanal nitrate, with the ratio between these two pathways differing for specific IN isomers (Wennberg et al., 2018, hereafter referred to as W2018). More details of the chemistry of IN are given in Sect. S1 of the Supplement.

In this study we deploy a new gas chromatography (GC) negative ionisation (NI) mass spectrometry (MS) system (Bew et al., 2016; Mills et al., 2016) in the field for the first time. By separating and unambiguously measuring individual IHN and ICN isomers along with propanone nitrate dur- 
ing a field campaign in Beijing, we are then able to test the isoprene chemistry of the MCM using a box model. We examine how the ratios of the IHN, primarily the $\beta$-IHN, can provide insight into the peroxy radicals (ISOPOO) derived from the $\mathrm{OH}$ oxidation of isoprene and in particular their relationship with NO (left-hand side of Fig. 1a), and we use data on ICN, IHN, and propanone nitrate to provide insight into the chemistry of the $\delta$-nitrooxy peroxy radicals $\left(\mathrm{INO}_{2}\right)$ formed from $\mathrm{NO}_{3}$ addition to isoprene and the (right-hand side of Fig. 1a).

\section{Nomenclature}

In this paper, when naming the IN, we have followed the nomenclature described by W2018. We assign numbers to the carbons of isoprene based on the conjugated butadiene backbone being comprised of carbons $1-4$, with the methyl substituent (carbon 5) connected to carbon 2. We refer to these carbons as "C\#" without subscripts (e.g. "C2"). For functionalised isoprene oxidation products, we drop the " $\mathrm{C}$ " when describing substituent positions; for example, (1$\mathrm{OH}, 2-\mathrm{ONO}_{2}$ )-isoprene hydroxy nitrate (IHN) has a hydroxy group at $\mathrm{C} 1$ and a nitrooxy group at $\mathrm{C} 2$. This is different to the way we named the IN in Mills et al. (2016), in which the IHN naming followed that of Lockwood et al. (2010) and the ICN were named similarly to the equivalent IHN, except they have "-al" as a suffix. We referred to acetone nitrate as NOA in Mills et al. (2016), whereas here we refer to it as propanone nitrate.

\section{Field campaign and measurements}

\subsection{Field campaign overview}

The GC-NI-MS system was deployed at the Institute of Atmospheric Physics (IAP, Chinese Academy of Sciences) in the summer of 2017 (21 May to 22 June) as part of the Atmospheric Pollution and Human Health in a Chinese Megacity (APHH-Beijing) programme (Shi et al., 2019). The IAP is located at $39.97^{\circ} \mathrm{N}, 116.38^{\circ} \mathrm{E}$ in a residential area between the 3rd and 4th north ring roads of Beijing. The site contained small trees and grass, with roads $150 \mathrm{~m}$ away. During the campaign air quality was poor (Fig. S1) with average concentrations of $\mathrm{PM}_{2.5}$ of $\sim 30 \mu \mathrm{g} \mathrm{m}^{-3}$ and average mixing ratios of $\mathrm{NO}_{2}$ of $15 \mathrm{ppb}, \mathrm{CO}$ of $450 \mathrm{ppb}$ and $\mathrm{O}_{3}$ of $\sim 45 \mathrm{ppb}$ (Shi et al., 2019). Details of the isoprene nitrate measurement technique are provided below, whilst details of instrumentation used for the supporting data are provided in the Supplement.

\subsection{Isoprene nitrate measurement method}

Seven individual isoprene nitrates were identified and quantified during the campaign (Figs. 1 and S2): two $\beta$-IHN ((1-
$\left.\left.\mathrm{OH}, 2-\mathrm{ONO}_{2}\right)-\mathrm{IHN},\left(4-\mathrm{OH}, 3-\mathrm{ONO}_{2}\right)-\mathrm{IHN}\right)$, four ICN (E-(1$\left.\mathrm{ONO}_{2}, 4-\mathrm{CO}\right)-\mathrm{ICN}, \mathrm{Z}-\left(1-\mathrm{ONO}_{2}, 4-\mathrm{CO}\right)-\mathrm{ICN}, \mathrm{E}-\left(4-\mathrm{ONO}_{2}\right.$, $\left.1-\mathrm{CO})-\mathrm{ICN}, \mathrm{Z}-\left(4-\mathrm{ONO}_{2}, 1-\mathrm{CO}\right)-\mathrm{ICN}\right)$, and propanone nitrate.

Measurements were made approximately hourly. Air was drawn at $10 \mathrm{~L} \mathrm{~min}^{-1}$ down a $2.5 \mathrm{~m}$ heated inlet $\left(3 / 8^{\prime \prime}\right.$ PFA and $45^{\circ} \mathrm{C}$ ) mounted on the roof (a height of approximately $3 \mathrm{~m}$ above the ground) of a mobile laboratory. Three different instrument setups were employed. (1) From the start of the measurements to 31 May, samples of $500 \mathrm{~mL}$ were taken off the inlet line down a $0.3 \mathrm{~m}$ length of $0.53 \mathrm{~mm}$ ID MxT200 transfer line held at $50^{\circ} \mathrm{C}$, preconcentrated on a Tenax adsorption trap at $35^{\circ} \mathrm{C}$ and $50 \mathrm{~mL} \mathrm{~min}^{-1}$, and injected onto the column via a metal six-port Valco valve by heating to $150{ }^{\circ} \mathrm{C}$ (Mills et al., 2016). A $30.5 \mathrm{~m}, 0.32 \mathrm{~mm}$ (internal diameter, ID) combination column was used, which was comprised of $28 \mathrm{~m}$ of Rtx-200 followed by $2.5 \mathrm{~m}$ of Rtx-1701 column. The GC oven was temperature profiled from 40 to $200{ }^{\circ} \mathrm{C}$, with a constant column flow of $4.5 \mathrm{~mL} \mathrm{~min}^{-1}$ of helium. (2) Between 10 and 16 June, the system was operated without a trap but instead consisted of direct injection of a $3 \mathrm{~mL}$ sample through a plastic Valco Cheminert valve connected to a short $0.32 \mathrm{~mm}$ ID combination column $(2.5 \mathrm{~m}$ of Rtx-200 joined to $0.5 \mathrm{~m}$ of Rtx-1701). The GC oven was temperature-programmed from 10 to $200^{\circ} \mathrm{C}$ and cooled with carbon dioxide $\left(\mathrm{CO}_{2}\right)$. A constant flow of $6.5 \mathrm{~mL} \mathrm{~min}^{-1}$ of helium was used as the carrier gas. (3) From 18 June to 22 June, the system again used the $30 \mathrm{~m}$ column and Tenax trapping as described above, but the metal valve was replaced with the Cheminert valve that was used for the direct injections.

Of the compounds reported here, all but those of $(1-\mathrm{OH}$, $\left.2-\mathrm{ONO}_{2}\right)$-IHN and E-(1-ONO $\left.2,4-\mathrm{CO}\right)-\mathrm{ICN}$ were confirmed by injection of known isomers (Mills et al., 2016) after the campaign. (1-OH, 2-ONO 2 )-IHN was identified based on its expected elution just before (4-OH, 3- $\mathrm{ONO}_{2}$ )-IHN (Nguyen et al., 2014) and the similarity of the observed ions to those of (4-OH, 3-ONO $\left.{ }_{2}\right)-\mathrm{IHN}$. The E-(1-ONO 2 , 4-CO)-ICN peak was identified by its relative elution position compared to the other ICN (Schwantes et al., 2015), its expected retention time estimated from the relative retention times of known $\delta$ IHN on this system and their aldehydic equivalents, and the similarity of observed ions to the other ICN.

During several comparisons of samples measured immediately before and after the valve was changed from metal to plastic and vice versa ( $1 \mathrm{~h}$ between samples), it was evident that the $\left(4-\mathrm{OH}, 3-\mathrm{ONO}_{2}\right)-\mathrm{IHN}$ and the ICN were lost to varying degrees on the metal valve as suggested by Crounse (John D. Crounse, personal communication, 2016), while simple alkyl nitrates were not. To account for this, all data obtained with the metal valve were scaled by the ratio of peak areas from the samples on either side of the valve changes to give results equivalent to those obtained when using the Cheminert valve. 
Calibrations for (4-OH, 3- $-\mathrm{ONO}_{2}$ )-IHN and propanone nitrate were derived from the relative sensitivity of the compound to that of n-butyl nitrate (Mills et al., 2016) corrected for the relative ion abundances of the specific measurement ions used for each compound ( $m / z 71$ and 73 , respectively). $M / z 73$ is a relatively minor ion for propanone nitrate, but we were unable to use a more major ion due to interferences from other compounds. N-butyl nitrate calibrations were performed every few days by attaching the transfer line to the standard in place of the inlet. We were unable to measure the relative sensitivities of $\left(1-\mathrm{OH}, 2-\mathrm{ONO}_{2}\right)-\mathrm{IHN}$ and the ICN to n-butyl nitrate directly. To obtain an estimate, we have assumed that the ICN and propanone nitrate all have the same total ion yields compared to those of n-butyl nitrate and scaled this relative total ion yield by the fraction of the ion yield that the measurement ion represents. Similarly, we have assumed that the total ion yields of $\left(1-\mathrm{OH}, 2-\mathrm{ONO}_{2}\right)$ $\mathrm{IHN}$ and (4-OH, 3-ONO ${ }_{2}$ )-IHN are the same (and thus the n-butyl nitrate $m / z$ 71: total IN ion ratio) and scaled this to reflect the proportion of the total ions that $m / z 101$ represents for $\left(1-\mathrm{OH}, 2-\mathrm{ONO}_{2}\right)-\mathrm{IHN}$.

\subsection{Isoprene nitrate measurement uncertainties}

We had previously determined the uncertainty for the measurement of the IN in the laboratory (including the GCMS precision and calibration uncertainties) to be $\pm 14 \%$ (Mills et al., 2016), which includes an uncertainty of $5 \%$ for the GC-MS precision. For determination of propanone nitrate in the field, we had to use a minor ion, and, with much smaller peaks, the precision was worse than it had been in the laboratory using more abundant ions. Based on the signal to noise on a peak, we estimate that the precision was $10 \%$ rather than the $5 \%$. We obtained ion counts in parts per trillion of $\mathrm{NO}_{y}$ for three isoprene nitrates: (4$\left.\mathrm{OH}, 3-\mathrm{ONO}_{2}\right)-\mathrm{IHN}$ (2030), propanone nitrate (2202), and $\mathrm{Z}-\left(4-\mathrm{OH}, 1-\mathrm{ONO}_{2}\right)-\mathrm{IHN}$ (2365). Using this range, we assume an additional uncertainty of $17 \%$ for the electron capture-ionisation efficiency of (1-OH, 2-ONO $\left.{ }_{2}\right)-\mathrm{IHN}$ and the ICN. During the campaign, we swapped between a metal and plastic valve twice. Using the peak areas for the last sample with the old valve and first sample with the new valve we calculated loss correction factors and the uncertainties in these correction factors of $\left(4-\mathrm{OH}, 3-\mathrm{ONO}_{2}\right)-\mathrm{IHN}$ $( \pm 5.2 \%)$, propanone nitrate $( \pm 6.4 \%)$, E- $\left(1-\mathrm{ONO}_{2}, 4-\mathrm{CO}\right)-$ $\mathrm{ICN}( \pm 14.8 \%), \mathrm{E}-\left(4-\mathrm{ONO}_{2}, 1-\mathrm{CO}\right)-\mathrm{ICN}( \pm 9.0 \%), \mathrm{Z}-(1-$ $\left.\mathrm{ONO}_{2}, 4-\mathrm{CO}\right)-\mathrm{ICN}( \pm 7.5 \%)$, and $\mathrm{Z}-\left(4-\mathrm{ONO}_{2}, 1-\mathrm{CO}\right)-\mathrm{ICN}$ $( \pm 9.2 \%)$. Loss corrections were applied to the data collected with the metal valve, and these additional uncertainties were included in the overall uncertainties calculated for the periods when the metal valve was used. Based on Mills et al. (2016), the detection limit (DL) of our system with the column and trap is $0.1 \mathrm{ppt}$, but this increased to $1 \mathrm{ppt}$ when run with direct injection. Combining these uncertainties, we get overall uncertainties for the measurements of the IN as shown in Table 1.

When determining the uncertainties in the ratios between IN, we first calculated the uncertainties for each individual IN measurement excluding the calibration uncertainties that were common to both. We then combined the uncertainties in these to derive overall uncertainties in the ratios. We only assessed the ratios of $\left(4-\mathrm{OH}, 3-\mathrm{ONO}_{2}\right)-\mathrm{IHN}$ : (1$\left.\mathrm{OH}, 2-\mathrm{ONO}_{2}\right)-\mathrm{IHN}$ in period 2, when we the used the plastic valve and direct injection; i.e. for the ratio $\left(4-\mathrm{OH}, 3-\mathrm{ONO}_{2}\right)-$ $\mathrm{IHN}$ : (1-OH, 2-ONO $\left.{ }_{2}\right)-\mathrm{IHN}$, we considered the GC-MS precision of $5 \%$ for each $\beta$-IHN and the additional $17 \%$ uncertainty for the electron capture-ionisation efficiency of (1$\mathrm{OH}, 2-\mathrm{ONO}_{2}$ )-IHN, plus the $1 \mathrm{ppt}$ for the DL. We only assessed the ICN ratio in period 3 when we the used the plastic valve, along with column and trap; i.e. we considered the GC-MS precision of $5 \%$ and the additional $17 \%$ uncertainty for the electron capture-ionisation efficiency for each of the ICN and $0.1 \mathrm{ppt}$ for the DL.

\section{MCM box model setup}

A zero-dimensional box model, utilising a subset of the chemistry described within the Master Chemical Mechanism, MCMv3.3.1 (Jenkin et al., 2015), was used to calculate the concentrations of the various isoprene nitrates for the campaign. The MCMv3.3.1 includes an update of the isoprene degradation chemistry to reflect findings of recent laboratory and theoretical studies.

The model was constrained by measured values of water vapour, temperature, pressure, $\mathrm{NO}, \mathrm{NO}_{2}, \mathrm{NO}_{3}, \mathrm{O}_{3}, \mathrm{CO}, \mathrm{SO}_{2}$, $\mathrm{HONO}$, and HCHO. Speciated VOC measurements of alcohols, alkanes, alkenes, dialkenes (including isoprene), multifunctional aromatics, carbonyls, and monoterpenes were included as further model constraints. The concentrations of $\mathrm{H}_{2}$ and $\mathrm{CH}_{4}$ were held constant at $500 \mathrm{ppb}$ and $1.8 \mathrm{ppm}$, respectively. The photolysis rates for $j\left(\mathrm{O}^{1} \mathrm{D}\right), j\left(\mathrm{NO}_{2}\right)$, and $j(\mathrm{HONO})$, calculated from the measured actinic flux and published absorption cross sections and quantum yields, were included as model inputs. Other photolysis frequencies used in the model were calculated. For UV-active species, such as $\mathrm{HCHO}$ and $\mathrm{CH}_{3} \mathrm{CHO}$, photolysis rates were calculated by scaling the ratio of clear-sky $j\left(\mathrm{O}^{1} \mathrm{D}\right)$ to observed $j\left(\mathrm{O}^{1} \mathrm{D}\right)$ to account for clouds. For species able to photolyse further into the visible, the ratio of clear-sky $j\left(\mathrm{NO}_{2}\right)$ to observed $j\left(\mathrm{NO}_{2}\right)$ was used. The variation of the clear-sky photolysis rates $(j)$ with solar zenith angle $(\chi)$ was calculated within the model using the following expression:

$j=l \cos (\chi)^{m} \times e^{-n \sec (\chi)}$,

with the parameters $l, m$, and $n$ optimised for each photolysis frequency (see Table 2 in Saunders et al., 2003).

The model was run for the entirety of the campaign (21 May 2017-25 June 2017) in overlapping $7 \mathrm{~d}$ segments, 
Table 1. Uncertainties in the measurements of the isoprene nitrates.

\begin{tabular}{llll}
\hline Isoprene nitrate & $\begin{array}{l}\text { Period 1 (metal valve, } \\
\text { column, and trap) }\end{array}$ & $\begin{array}{l}\text { Period 2 (plastic valve } \\
\text { and direct injection) }\end{array}$ & $\begin{array}{l}\text { Period 3 (plastic valve, } \\
\text { column, and trap) }\end{array}$ \\
\hline$\left(4-\mathrm{OH}, 3-\mathrm{ONO}_{2}\right)-\mathrm{IHN}$ & $15 \%+0.1 \mathrm{ppt}$ & $14 \%+1 \mathrm{ppt}$ & $14 \%+0.1 \mathrm{ppt}$ \\
$\left(1-\mathrm{OH}, 2-\mathrm{ONO}_{2}\right)-\mathrm{IHN}$ & - & $22 \%+1 \mathrm{ppt}$ & - \\
$\mathrm{E}-\left(1-\mathrm{OH}, 4-\mathrm{ONO}_{2}\right)-\mathrm{ICN}$ & $27 \%+0.1 \mathrm{ppt}$ & - & $22 \%+0.1 \mathrm{ppt}$ \\
$\mathrm{E}-\left(4-\mathrm{OH}, 1-\mathrm{ONO}_{2}\right)-\mathrm{ICN}$ & $24 \%+0.1 \mathrm{ppt}$ & - & $22 \%+0.1 \mathrm{ppt}$ \\
$\mathrm{Z}-\left(1-\mathrm{OH}, 4-\mathrm{ONO}_{2}\right)-\mathrm{ICN}$ & $23 \%+0.1 \mathrm{ppt}$ & - & $22 \%+0.1 \mathrm{ppt}$ \\
$\mathrm{Z}-\left(4-\mathrm{OH}, 1-\mathrm{ONO}_{2}\right)-\mathrm{ICN}$ & $24 \%+0.1 \mathrm{ppt}$ & - & $22 \%+0.1 \mathrm{ppt}$ \\
Propanone nitrate & $18 \%+0.1 \mathrm{ppt}$ & - & $17 \%+0.1 \mathrm{ppt}$ \\
\hline
\end{tabular}

with the model constraints updated every $15 \mathrm{~min}$. By this method, a model time series was produced that could be directly compared with observations and from which diel averages were generated. There was a spike of very high concentrations of isoprene in the early hours of the morning of 16 June 2017, which led to extremely high concentrations of modelled ICN, propanone nitrate, and (4-OH, 1- $\left.\mathrm{ONO}_{2}\right)$ IHN. These have been removed from the diel averages presented in this paper. Fluxes through each reaction were calculated for every $15 \mathrm{~min}$ period to allow an analysis of the production and loss terms of the chemical species.

The loss due to mixing of all non-constrained modelgenerated species, including the speciated isoprene nitrates, was parameterised and evaluated by comparing the modelpredicted glyoxal concentration with the observed glyoxal concentration. Applying a loss rate proportional to the observationally derived mixed-layer height (Fig. S4), the model was able to reproduce glyoxal observations reasonably well (Fig. S4). As a result of this first-order loss process, the partial lifetime of the model-generated species was $\sim 2 \mathrm{~h}$ at night and then decreased rapidly to a lifetime of $<30 \mathrm{~min}$ in the morning as the mixed layer grew, effectively simulating ventilation of the model box. With the collapse of the mixed layer in the late afternoon, the model lifetime with respect to ventilation of glyoxal (and other model-generated species) increased. However, the model has a tendency to underestimate glyoxal concentrations between 16:00 and 00:00 LT. This underestimation suggests that either the lifetime with respect to ventilation should be even longer or that the model is underestimating oxidation processes that lead to glyoxal production at these times. We do not consider uptake of glyoxal onto aerosol, the rate of which is highly uncertain (Volkamer et al., 2007; Washenfelder et al., 2011; Li et al., 2016). Including one would have led to use of a slower ventilation rate. The same first-order ventilation loss was applied to all species and no specific assumptions were made about the background concentrations. Consequently, the rate of mixing may be overestimated for longer-lived species with significant background concentrations and conversely underestimated for shorter-lived species.

\section{Results and discussion}

\section{$5.1 \beta$-IHN}

Figures 2 and S3 compare the measured and modelled $\beta$ IHN. The shaded areas in Fig. 2 represent \pm 1 SD in the data for each hour of the day and illustrate the large day-to-day variability in the mixing ratios of $\beta$-IHN. Note that for (1$\mathrm{OH}, 2-\mathrm{ONO}_{2}$ )-IHN there are only $6 \mathrm{~d}$ worth of data, and thus the average diel patterns are strongly affected by the dayto-day variability. This is particularly the case for the measurements where three of the hourly bins contain just one measurement, while the rest have between three and eight measurements.

The observed $\beta$-IHN exhibit diel patterns that are broadly in agreement with those modelled and consistent with daytime formation from $\mathrm{OH}$ oxidation of isoprene and a shift in competition from the reactions of isoprene-derived peroxy radicals (ISOPOO) with $\mathrm{NO}$ to reaction with $\mathrm{HO}_{2}$ as mixing ratios of NO decline from an early morning peak (Fig. S5) and those of the peroxy radicals maximise in the mid-afternoon (Whalley et al., 2021). The observed $\beta$-IHN peak around midday, and these levels are mostly maintained until around sunset when they decline to reach minimum values just after sunrise. This pattern is also broadly similar to that of total IHN observed during the Southern Oxidant and Aerosol Study (SOAS) (Xiong et al., 2015).

The absolute values of the observed (1-OH, 2-ONO 2 )-IHN daytime mixing ratios are very similar to those modelled (Figs. 2 and S3). On some days, the observed and modelled (4-OH, 3-ONO 2 )-IHN mixing ratios are reasonably similar, but on a few days the model simulates considerably larger mixing ratios than observed (Fig. S3) such that the mean daytime observed mixing ratios tend to be lower than modelled and exhibit far less day-to-day variability (Fig. 2). The observed evening mixing ratios of both $\beta$-IHN are higher than modelled, suggesting that, like glyoxal, the model overestimates their loss with respect to ventilation. Alternatively, there may be greater production or slower chemical loss than simulated. It is worth noting that the MCM assumes $8 \%$ of the $\mathrm{OH}$ addition to isoprene occurs at the $\mathrm{C} 2$ and $\mathrm{C} 3$ positions instead of the $\mathrm{C} 1$ and $\mathrm{C} 4$ positions, thus reducing the poten- 
(a)

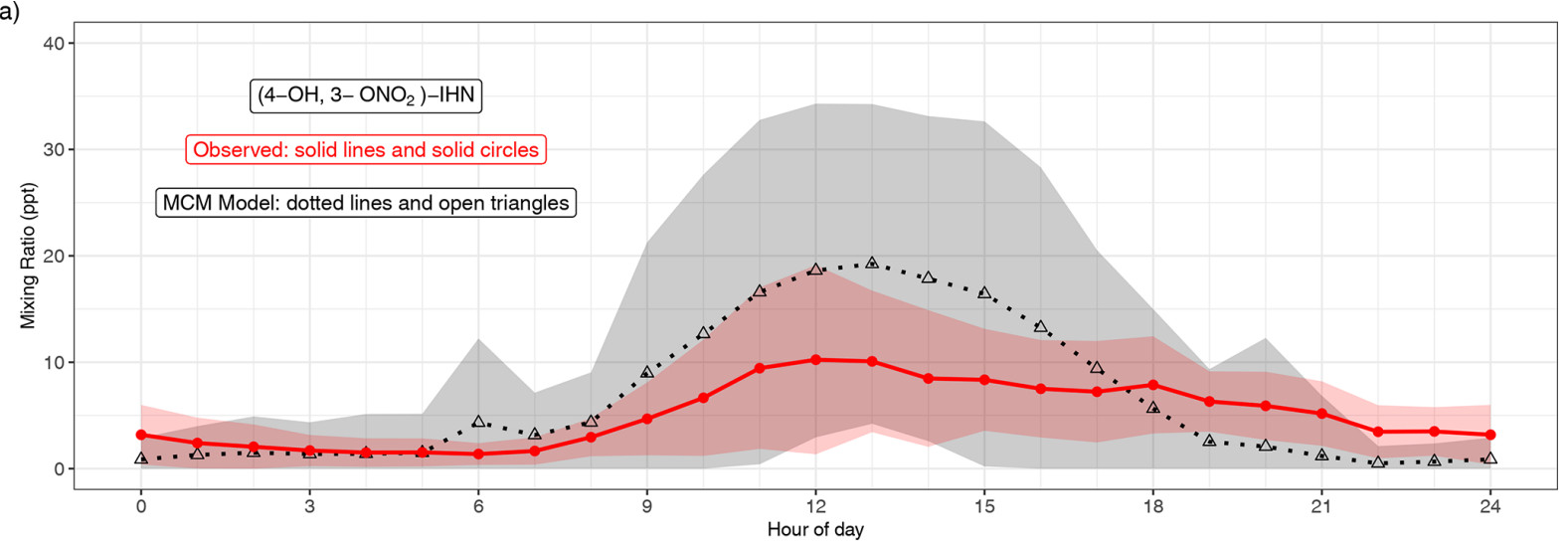

(b)

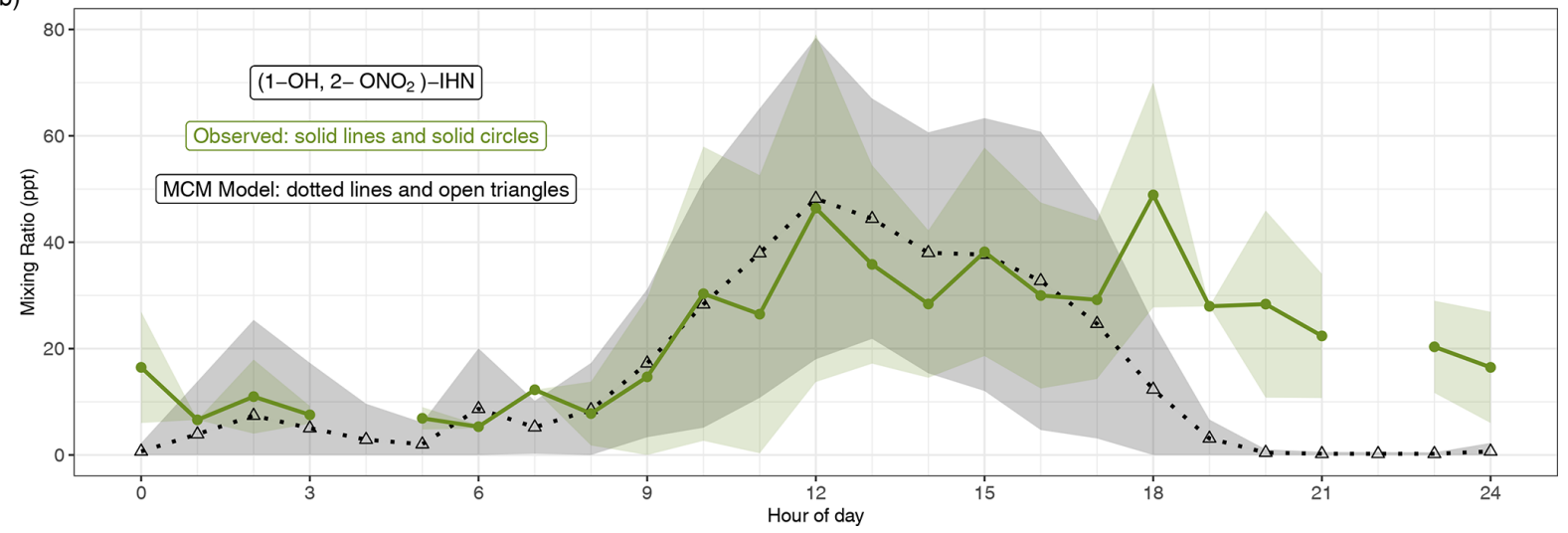

Figure 2. Modelled and observed mixing ratios of (a) $\left(4-\mathrm{OH}, 3-\mathrm{ONO}_{2}\right)-\mathrm{IHN}$ and (b) (1-OH, 2-ONO 2$)-\mathrm{IHN}$. Data points are the mean, and the shaded areas represent $\pm 1 \mathrm{SD}$ in the variability of values for each hour of the day.

tial to form (1-OH, 2-ONO 2$)-\mathrm{IHN}$ or $\left(4-\mathrm{OH}, 3-\mathrm{ONO}_{2}\right)-\mathrm{IHN}$, whereas $\mathrm{W} 2018$ recommend that the $\mathrm{C} 2$ and $\mathrm{C} 3$ additions are negligible.

To limit the impact of ventilation on the comparison between the model and observations we compare the ratio of (1-OH, 2-ONO 2 )-IHN to (4-OH, 3-ONO 2 )-IHN (Figs. 3 and 4). When looking at the time series (Fig. 3) of this ratio, the model and measurements often agree within the measurement uncertainties, although there are times when the observed values are greater than modelled. The shaded areas in Fig. 4 represent \pm 1 SD in the data for each hour of the day. The large variability in the observed data is caused by some hours having very few data points, sometimes affected by a single high value (Fig. 3). The observed mean ratios are generally higher than the modelled mean, although there is often agreement within the day-to-day variability.

It should be noted that the ratio we obtain from our measurements is not based on an independent calibration for (1$\mathrm{OH}, 2-\mathrm{ONO}_{2}$ )-IHN but is instead based on the assumption that the analytical system has the same sensitivity to $(1-\mathrm{OH}$, 2- $\mathrm{ONO}_{2}$ )-IHN as it does to $\left(4-\mathrm{OH}, 3-\mathrm{ONO}_{2}\right)-\mathrm{IHN}$. We have tried to account for this in the uncertainty calculations by assuming that the error in this sensitivity is equal to the per- centage range of sensitivities that we observed for the other IN (see Sect. 3.3). It is possible that this is an underestimate.

There are four main factors that determine the ratio of the $\beta$-IHN: (1) the yields of their respective peroxy radicals (ISOPOO) following oxidation of isoprene by $\mathrm{OH}$ addition $(\varphi),(2)$ the fraction of the respective ISOPOO that reacts with NO $(\gamma)$, (3) the branching ratios for the formation of the IHN from the reaction of NO with the ISOPOO $(\alpha)$, and (4) the relative loss rates of the $\beta$-IHN, including via deposition.

For the first two factors, the concentration of NO is largely the determining influence. The adducts formed from $\mathrm{OH}$ addition to a specific $\mathrm{C}$ in isoprene can form a $\beta$-ISOPOO and either an $\mathrm{E}$ or $\mathrm{Z} \delta$-ISOPOO upon reaction with $\mathrm{O}_{2}$ (Fig. 5). These reactions are reversible and, since the lifetimes of these peroxy radicals differ, they inter-convert within two subgroups defined by the position of the $\mathrm{OH}$ (i.e. $\mathrm{C} 1$ on the left-hand side of Fig. 5 and $\mathrm{C} 4$ on the right-hand side). NO is often present in large amounts (Figs. S2 and S5) and thus reaction with it is the dominant loss process for the ISOPOO. However, at low NO mixing ratios other losses of the ISOPOO become relatively more important, and the different rates of $1,6 \mathrm{H}$ atom shift isomerisation of the $\mathrm{Z}$ - 


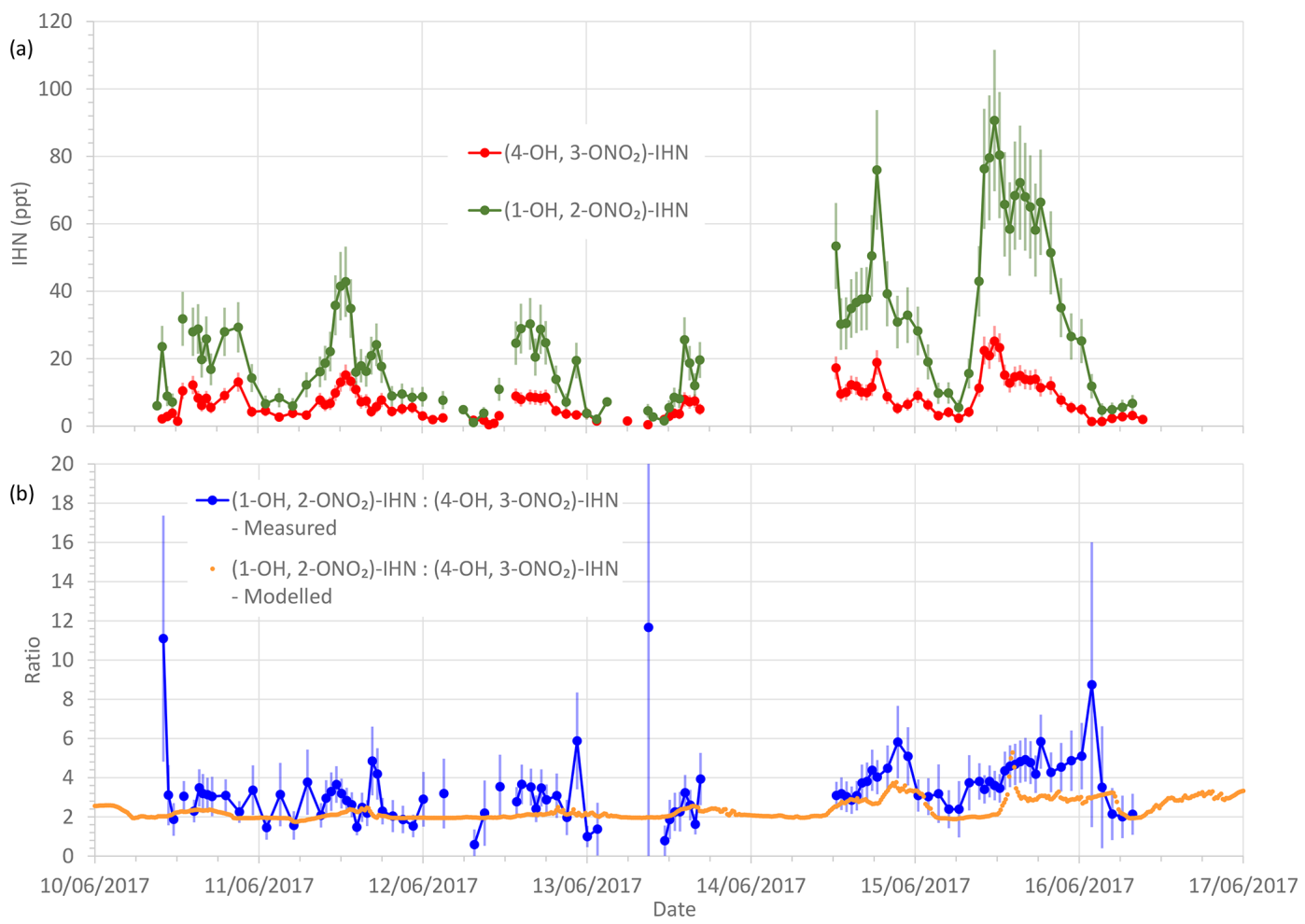

Figure 3. (a) Measured $\beta$-IHN mixing ratios. (b) Measured and modelled ratio (1-OH, 2-ONO 2$)-\mathrm{IHN}$ :(4-OH, 3-ONO 2$)-\mathrm{IHN}$. Error bars are the measurement uncertainties (see Sect. 3.3 for details).

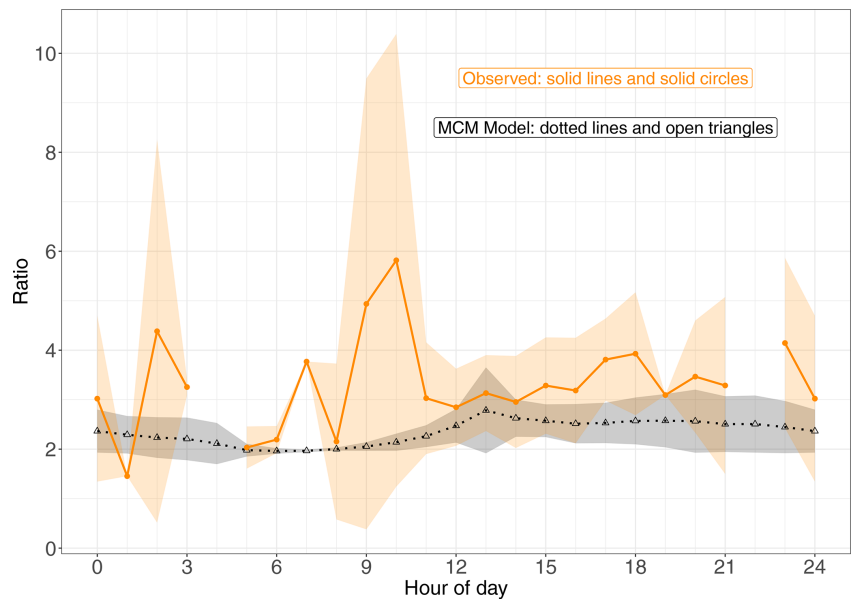

Figure 4. Modelled and observed (1-OH, 2-ONO 2$)-\mathrm{IHN} /(4-\mathrm{OH}$, $\left.3-\mathrm{ONO}_{2}\right)-\mathrm{IHN}$ ratio. Data points are the means and the shaded areas represent $\pm 1 \mathrm{SD}$ in the variability of values for each hour of the day.

(1-OH, 4-OO)-ISOPOO and Z-(4-OH, 1-OO)-ISOPOO in particular mean that redistribution of the ISOPOO within each sub-group differs, such that (1-OH, 2-OO)-ISOPOO increases relative to (4-OH, 3-OO)-ISOPOO. Consequently, at lower NO mixing ratios the modelled ratio of $\varphi-(1-\mathrm{OH}, 2-$ OO)-ISOPOO to $\varphi$-(4-OH, 3-OO)-ISOPOO becomes larger (Fig. 6a). For mixing ratios of NO greater than $\sim 2 \mathrm{ppb}$, the ratio of the values of $\varphi$ decreases approximately linearly from around 2 to about 1.7 at $100 \mathrm{ppb}$ of NO. The ratio of the kinetic yields in the MCM is 1.58 , which is the ratio of the values of $\varphi$ that we get if we switch off the reverse pathway of the $\mathrm{O}_{2}$ reactions. This implies that even at $100 \mathrm{ppb}$ of $\mathrm{NO}$, the ratio of the yields of the (1-OH, 2-OO)-ISOPOO to (4-OH, $3-\mathrm{OO})$-ISOPOO is shifted to values slightly greater than the kinetic ratio. At $\mathrm{NO}$ mixing ratios less than $\sim 2 \mathrm{ppb}$, the ratio of the values of $\varphi$ increase with decreasing NO, such that at $\sim 10-100 \mathrm{ppt}$ NO the ratio is typically between 2.5 and 4 .

The rates at which the ISOPOO are assumed to be lost via the reactions with $\mathrm{NO}, \mathrm{HO}_{2}$, and $\mathrm{NO}_{3}$ are the same for both $\beta$-ISOPOO. However, the rate constants for reaction of (1-OH, 2-OO)-ISOPOO with $\mathrm{RO}_{2}$ and for its rate of isomerisation are slower than those of (4-OH, 3-OO)-ISOPOO. At lower NO mixing ratios, these reactions become relatively more important, and thus the modelled value of $\gamma$ is lower for (4-OH, 3-OO)-ISOPOO than for (1-OH, 2-OO)-ISOPOO, and the ratio of $\gamma-(1-\mathrm{OH}, 2-\mathrm{OO})-\mathrm{ISOPOO}$ to $\gamma-(4-\mathrm{OH}, 3-$ OO)-ISOPOO is larger (Fig. 6b). This is further enhanced as the concentrations of $\mathrm{RO}_{2}$ can also be much greater at the lower NO concentrations, particularly below $1 \mathrm{ppb}$ NO (Fig. 6c), which leads to the ratio in the $\gamma$ values often being considerably greater than 1 at $\mathrm{NO}$ concentrations below 100 ppt.

It should be noted that the MCM model underestimates the measured $\mathrm{RO}_{2}$ mixing ratios (Whalley et al., 2021). This 


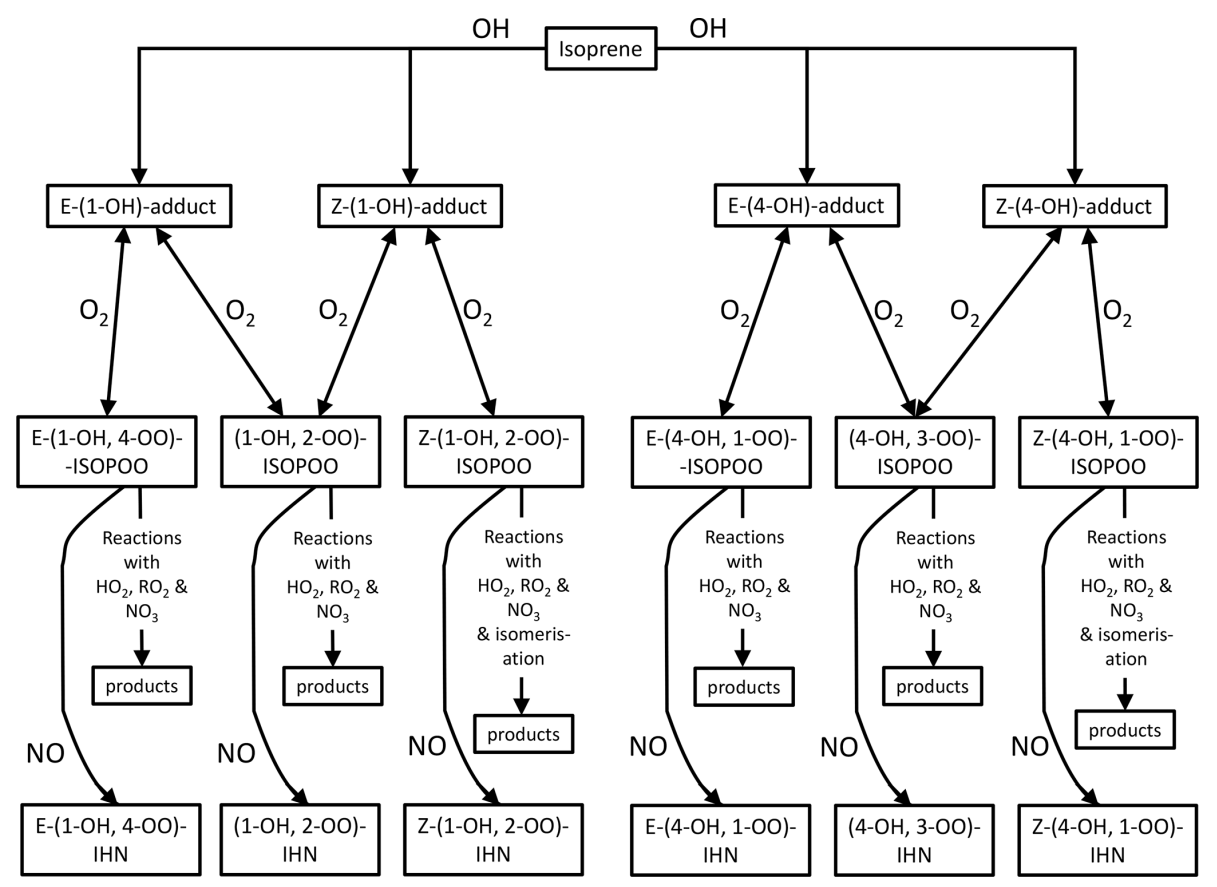

Figure 5. Schematic of the formation of the $\mathrm{IHN}$ following addition of $\mathrm{OH}$ to the $\mathrm{C} 1$ and $\mathrm{C} 4$ positions.

will lead to underestimation of the ratio of $\gamma-(1-\mathrm{OH}, 2-\mathrm{OO})$ ISOPOO to $\gamma$-(4-OH, 3-OO)-ISOPOO, primarily at mixing ratios of $\mathrm{NO}$ below $\sim 2 \mathrm{ppb}$. This might explain some of the differences between the modelled and observed $\beta$-IHN ratios.

The net effect of these relationships is that the modelled ratio of (1-OH, 2-OO)-ISOPOO to (4-OH, 3-OO)-ISOPOO increases with decreasing NO (Fig. 6d); i.e. for NO mixing ratios greater than $2 \mathrm{ppb}$ the ratio is around $1.7-2.0$, but at NO mixing ratios less than 2 ppb the ratio increases up towards a value of around 4 . The ratio of the rate of production of (1-OH, 2- $\left.\mathrm{ONO}_{2}\right)$-IHN to $\left(4-\mathrm{OH}, 3-\mathrm{ONO}_{2}\right)-\mathrm{IHN}$ will have the same relationship with $\mathrm{NO}$ as the ratio of their precursor ISOPOO since the MCM assumes that the branching ratios for the formation of the two $\beta$-IHN from the reaction of NO with the ISOPOO (i.e. $\alpha$, third factor) are the same. However, there are still considerable uncertainties in these branching ratios (Sect. S1.1).

As for the loss processes of the $\beta$-IHN (fourth factor), the dominant loss in the model is the mixing term, which is set at the same rate for both $\beta$-IHN. Photolysis is assumed to be faster for $\left(1-\mathrm{OH}, 2-\mathrm{ONO}_{2}\right)-\mathrm{IHN}$ than for $(4-\mathrm{OH}, 3-$ $\mathrm{ONO}_{2}$ )-IHN in the MCM, but it is only a minor loss process. However, (1-OH, 2- $\left.\mathrm{ONO}_{2}\right)-\mathrm{IHN}$ reacts with both $\mathrm{OH}$ and $\mathrm{O}_{3}$ more slowly than $\left(4-\mathrm{OH}, 3-\mathrm{ONO}_{2}\right)-\mathrm{IHN}$ does, and since the dominant chemical loss process for the $\beta$-IHN by far is their reactions with $\mathrm{OH}$, the net effect of these loss processes is to increase the ratio of (1-OH, 2- $\left.\mathrm{ONO}_{2}\right)-\mathrm{IHN}$ to $(4-\mathrm{OH}, 3-$ $\mathrm{ONO}_{2}$ )-IHN above their production ratio. The diel pattern in $\mathrm{OH}$ (Fig. S5) will tend to increase the ratio of (1-OH, 2$\mathrm{ONO}_{2}$ )-IHN to (4-OH, 3-ONO 2$)-\mathrm{IHN}$ during the daytime.

Overall, this means that the modelled ratio of $(1-\mathrm{OH}, 2-$ $\left.\mathrm{ONO}_{2}\right)$-IHN to $\left(4-\mathrm{OH}, 3-\mathrm{ONO}_{2}\right)-\mathrm{IHN}$ increases with decreasing NO mixing ratios (Fig. 6e) (as also seen by Jenkin et al. (2015) in a box model using the MCM) and generally does not drop below the ratio of the $\beta$-ISOPOO (Fig. 6d). In the conditions modelled for Beijing it ranges from between 1.75 and 2.0 at $\mathrm{NO}$ mixing ratios above $\sim 30 \mathrm{ppb}$, typically rising up to between 2 and 3 but sometimes up to 4 at NO mixing ratios below $1 \mathrm{ppb}$. There are several cases at these low NO mixing ratios when the ratio of the $\beta$-IHN is below the ratio of the $\beta$-ISOPOO, but these occur at night when the production rates and the mixing ratios of the $\beta$-IHN are very small.

In comparison, the observed ratios of (1-OH, 2- $\left.-\mathrm{ONO}_{2}\right)$ IHN to $\left(4-\mathrm{OH}, 3-\mathrm{ONO}_{2}\right)-\mathrm{IHN}$ show a similar but weaker relationship with NO (Fig. 6f). The strength of the observed relationship is limited by the number of data points and uncertainties in the measurements but shows a tendency for relatively more (1-OH, 2- $\left.\mathrm{ONO}_{2}\right)-\mathrm{IHN}$ at $\mathrm{NO}$ mixing ratios of less than $1 \mathrm{ppb}$.

Newland et al. (2021) point out that during the campaign a high $\mathrm{NO}_{x}$ environment existed in the morning but then switched to a low $\mathrm{NO}_{x}$ environment in the afternoon. The mean hourly NO mixing ratios were typically above $2 \mathrm{ppb}$ between 06:00 and 12:00 LT but mostly below this value in the afternoon (Fig. S5). The relationship between $\beta$-IHN and $\mathrm{NO}$ as illustrated in (Fig. 6e) largely explains why the modelled ratio of the $\beta$-IHN (Fig. 4 ) is $\sim 2$ and exhibits little 

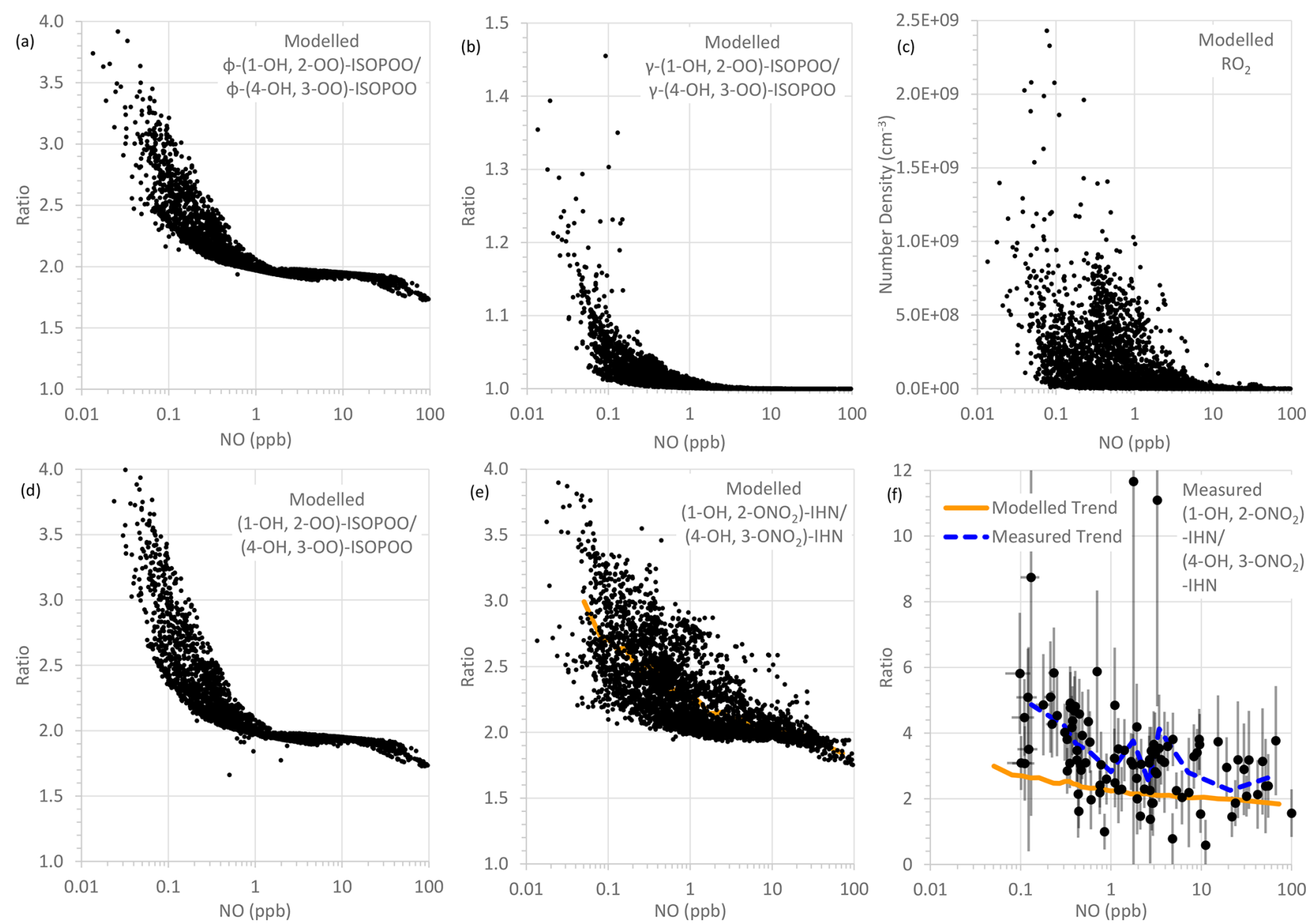

Figure 6. Modelled and measured parameters as a function of NO mixing ratio: (a) modelled ratio of $\varphi$-(1-OH, 2-OO)-ISOPOO to $\varphi$-(4$\mathrm{OH}, 3-\mathrm{OO})-\mathrm{ISOPOO}$, (b) modelled ratio of $\gamma$-(1-OH, 2-OO)-ISOPOO to $\gamma$-(4-OH, 3-OO)-ISOPOO, (c) modelled $\mathrm{RO}_{2}$ number density, (d) modelled ratio of (1-OH, 2-OO)-ISOPOO to (4-OH, 3-OO)-ISOPOO, (e) modelled ratio of (1-OH, 2-ONO $)_{2}$ - $\left.\mathrm{IHN}_{\mathrm{HN}}(4-\mathrm{OH}, 3-\mathrm{ONO})_{2}\right)$ $\mathrm{IHN}$, and (f) measured ratio of $\left(1-\mathrm{OH}, 2-\mathrm{ONO}_{2}\right)-\mathrm{IHN}$ to $\left(4-\mathrm{OH}, 3-\mathrm{ONO}_{2}\right)-\mathrm{IHN}$ (error bars are the measurement uncertainties; see Sect. 3.3 for details). In panel (e), the orange line is a trend line produced by plotting the mean modelled (1-OH, 2- $\left.-\mathrm{ONO}_{2}\right)-\mathrm{IHN}_{\mathrm{H}}$ to $(4-\mathrm{OH}, 3-\mathrm{ONO} 2)-$ IHN ratio for each bin of $100 \mathrm{NO}$ mixing ratios. This same line is plotted in panel (f) for comparison with the observed data. The dashed blue line in panel (f) is a trend line produced by plotting the mean measured (1-OH, 2- $\left.\mathrm{ONO}_{2}\right)-\mathrm{IHN}_{\text {to }}(4-\mathrm{OH}, 3-\mathrm{ONO} 2)-\mathrm{IHN}$ ratio for each bin of nine NO mixing ratios.

variability between about 06:00 and 09:00 LT and then rises up to around 2.5 in the afternoon.

Our mean observed (1-OH, 2-ONO $\left.{ }_{2}\right)-\mathrm{IHN}$ to $(4-\mathrm{OH}, 3-$ $\mathrm{ONO}_{2}$ )-IHN ratio of $\sim 3.4$ is higher than the daytime values reported by Vasquez et al. (2018) in the PROPHET campaign $(\sim 2.6)$ and in Pasadena $(\sim 1.4)$, but their data show a similar pattern to ours in that the ratio is higher in the low $\mathrm{NO}_{x}$ environment of PROPHET compared to the high $\mathrm{NO}_{x}$ environment in Pasadena. We cannot rule out calibration differences affecting this comparison and, like us, Vasquez et al. (2018) relied on relative calibration estimates. In addition, differences in the observed $\beta$-IHN ratios may be due to the amount and reactivity of the peroxy radicals present in the different studies. However, the ratio of 1.4 observed for Pasadena is lower than the kinetic $\varphi$ ratios of 1.58 and
1.85 based on MCM and W2018 kinetic yields, respectively. Xiong et al. (2015) calculate a ratio ranging from 2.6 to 6.0 based on the conditions experienced in SOAS.

\section{$5.2 \delta$-ICN}

The MCM assumes all of the $\delta$-ICN formed can be represented by a single species, $\left(1-\mathrm{ONO}_{2}, 4-\mathrm{CO}\right)-\mathrm{ICN}$, called $\mathrm{NC} 4 \mathrm{CHO}$. We shall therefore compare the sum of the observed $\delta$-ICN with the modelled $\mathrm{NC} 4 \mathrm{CHO}$ and then look at the speciation as exhibited in the observations.

Both the observed and modelled total $\delta$-ICN peak at night, but the observed total was typically less than that modelled (Figs. 7 and S6), particularly on occasions at night (Fig. S6). This is also illustrated by the large day-to-day variability in the modelled diel patterns not seen in the observations 
(a)

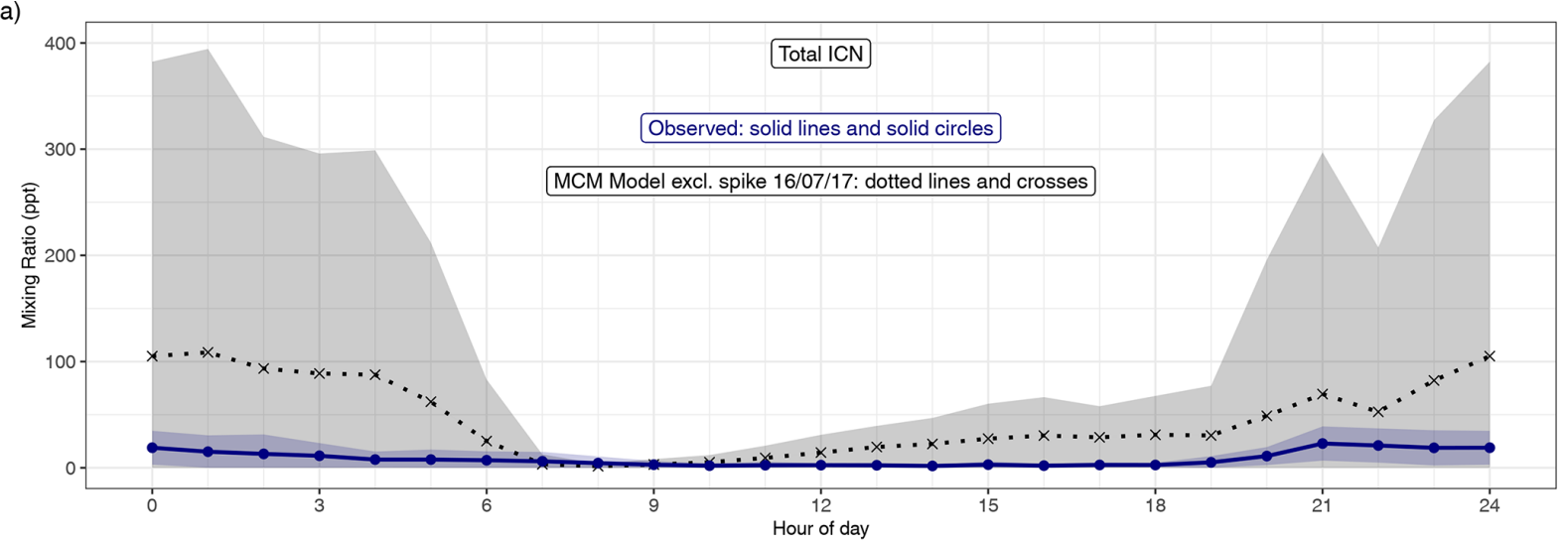

(b)

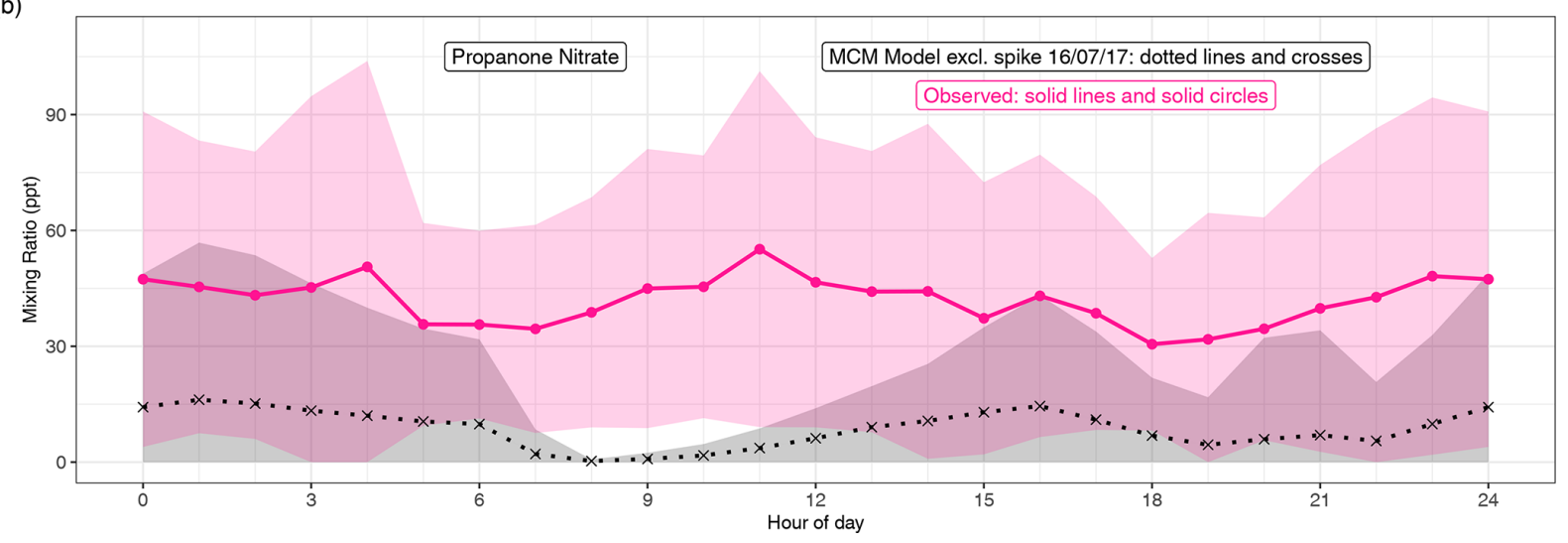

Figure 7. (a) Diel pattern of total ICN as modelled using the MCM and measured. For the MCM this is the species NC4CHO, whilst the measurements are the sum of the four $\delta$-ICN (E and Z-(1-ONO $2,4-\mathrm{CO})-\mathrm{ICN}$ and E and Z-(4-ONO $2,1-\mathrm{CO})-\mathrm{ICN})$. (b) Diel pattern of propanone as modelled using the MCM and measured. Data points are the means and the shaded areas represent \pm 1 SD in the variability of values for each hour of the day.

(Fig. 7). The observed diel patterns in the ICN can be seen more clearly in Figs. 8 and S5 and show maximum values in the early night and minimum values during the daytime.

The source of $\delta$-ICN is via the addition of $\mathrm{NO}_{3}$ to isoprene followed by addition of $\mathrm{O}_{2}$. This produces $\delta$-nitrooxy peroxy radicals $\left(\mathrm{INO}_{2}\right)(\mathrm{NISOPO} 2$ in the $\mathrm{MCM})$ and, in the conditions simulated for Beijing, the major loss of $\mathrm{INO}_{2}$ is reaction with $\mathrm{NO}$ to form $\mathrm{NO}_{2}$ and a $\delta$-nitrooxy alkoxy radical (NISOPO in the MCM), which then reacts rapidly with $\mathrm{O}_{2}$ to form the $\delta$-ICN. Other production pathways for $\delta$-ICN exist in the MCM, but the reaction of $\mathrm{INO}_{2}$ with $\mathrm{NO}$ is by far the dominant source of $\delta$-ICN in our simulations. There are some nights when the model simulates large sources of $\mathrm{INO}_{2}$, but typically the modelled production of $\mathrm{INO}_{2}$ maximises in the mid-afternoon. The model is constrained by the observed concentrations of isoprene and $\mathrm{NO}_{3}$, and in the mid-afternoon the observed isoprene mixing ratios are still high and $\mathrm{NO}_{3}$ is around 2 ppt (Fig. S5).

The dominant loss of $\delta$-ICN in the model is the ventilation term, which is greatest during the daytime when the mixed layer is fully developed. The next most important loss pro- cesses for $\delta$-ICN are simulated to be photolysis and reaction with $\mathrm{OH}$, which are also both predominantly daytime losses.

The net effect of the production and loss terms is that the modelled $\delta$-ICN increases during the afternoon and maximises during the night-time, and the observed $\delta$-ICN are broadly consistent with this result (Figs. 7, S5 and S6). We observed around 1-2 ppt E-(4-ONO $2,1-\mathrm{CO})-\mathrm{ICN}$ during the daytime, and this requires a significant daytime source assuming a lifetime of around $30 \mathrm{~min}$ with respect to photolysis (based on a value of $4.6 \times 10^{-4} \mathrm{~s}^{-1}$ for a solar zenith angle of $0^{\circ}$ and adjusting for latitude, time of year, and time of day; Xiong et al., 2016). This source is consistent with the observed presence of $\mathrm{NO}_{3}$ during the daytime. However, the considerably larger modelled mixing ratios of $\delta$-ICN compared to the observed suggests that the modelled source via $\mathrm{NO}_{3}$ oxidation of isoprene might be too fast or that the loss processes are too slow.

The same ventilation process has been applied to all model-generated species (Sect. 4). For glyoxal, (1-OH, 2$\left.\mathrm{ONO}_{2}\right)-\mathrm{IHN}$, and (4-OH, 3-ONO 2$)-\mathrm{IHN}$, the model tends to overestimate the decrease in concentrations from the late af- 


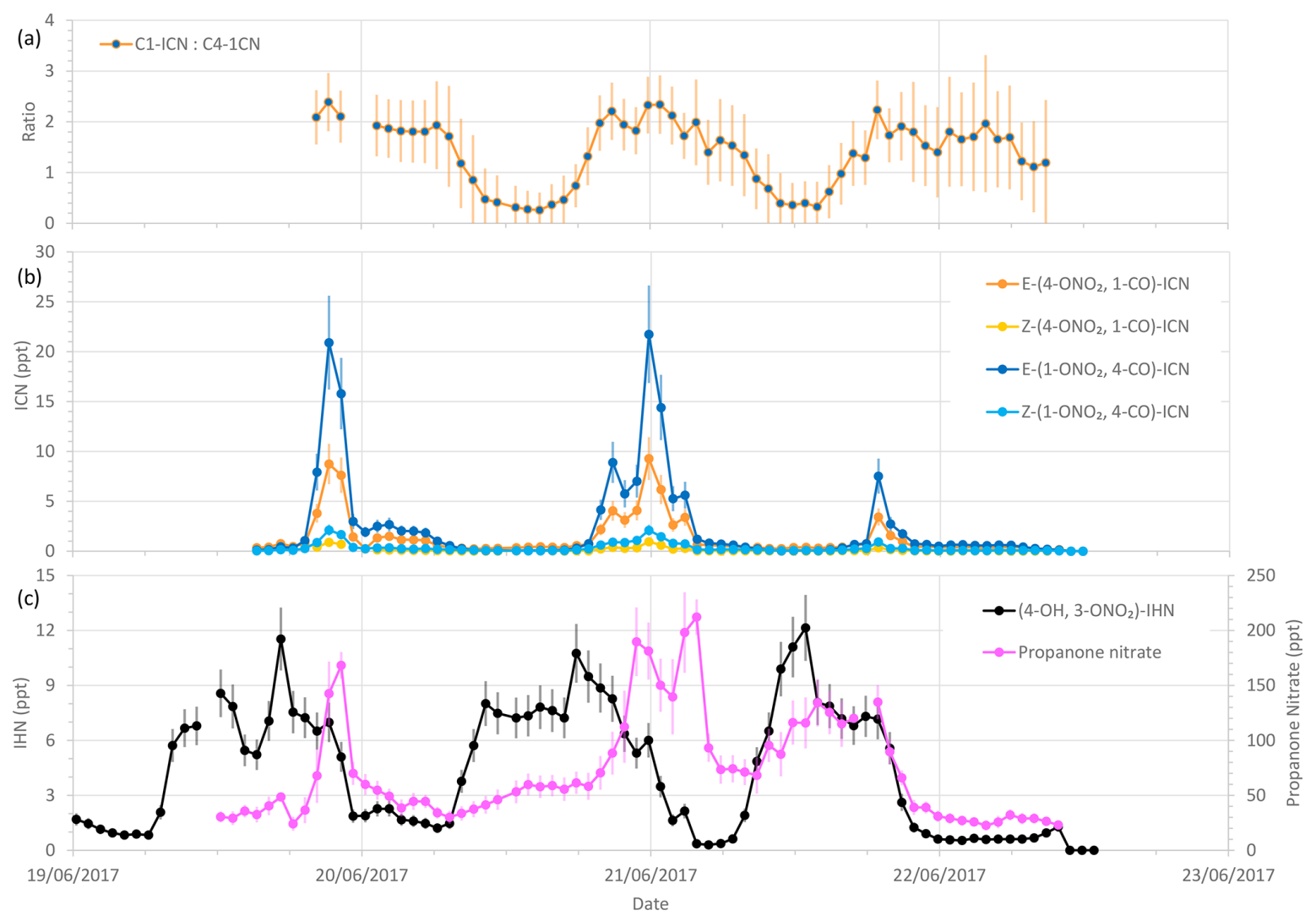

Figure 8. Measured $\delta$-ICN mixing ratios and ratios of $\mathrm{C} 1-\mathrm{ICN}$ to $\mathrm{C} 4-\mathrm{ICN}$, along with (4-OH, 3-ONO 2 )-IHN and propanone nitrate mixing ratios during the last $4 \mathrm{~d}$ of the summer campaign. Error bars are the measurement uncertainties (see Sect. 3.3 for details). The vertical grid lines indicate midnight on each day.

ternoon onwards, suggesting that the lifetime with respect to ventilation should be longer at these times but increasing the lifetime of $\delta$-ICN would lead to their further overestimation. Applying the same loss term to all model species is of course an approximation, not least because the dilution term depends on the concentration of the species in the diluent air.

The MCM uses a photolysis frequency for $\delta$-ICN based on that measured for propanone nitrate, which is equivalent to $3.16 \times 10^{-4} \mathrm{~s}^{-1}$ for a solar zenith angle of $0^{\circ}$. Xiong et al. (2016) determined a higher rate of $4.6 \times 10^{-4} \mathrm{~s}^{-1}$ for (4$\mathrm{ONO}_{2}, 1-\mathrm{CO}$ )-ICN for a solar zenith angle of $0^{\circ}$. Increasing rate of photolysis in the model would not only reduce the daytime increase in $\delta$-ICN but would also reduce the amount of modelled $\delta$-ICN that would persist into the night.

Reaction with $\mathrm{OH}$ constitutes a similar size loss for $\delta$-ICN as photolysis in the model. The MCM treats all the $\delta$-ICN as $\left(1-\mathrm{ONO}_{2}, 4-\mathrm{CO},-\mathrm{ICN}\right.$ and uses a rate constant for reaction with $\mathrm{OH}$ of $4.16 \times 10^{-11} \mathrm{~cm}^{3} \mathrm{~s}^{-1}$. W2018 suggests a lower rate constant for reaction of $\mathrm{OH}$ with $\left(1-\mathrm{ONO}_{2}, 4-\mathrm{CO}\right)$ ICN $\left(3.4 \times 10^{-11} \mathrm{~cm}^{3} \mathrm{~s}^{-1}\right)$ but a similar rate for $\left(4-\mathrm{ONO}_{2}, 1\right.$ CO)-ICN $\left(4.1 \times 10^{-11} \mathrm{~cm}^{3} \mathrm{~s}^{-1}\right)$. Therefore, treating the two separately in the model and using the W2018 recommended rate constants would overall reduce the loss of $\delta$-ICN with respect to $\mathrm{OH}$, increasing discrepancy with the model.

Night-time losses of $\delta$-ICN are reaction with $\mathrm{O}_{3}$ and $\mathrm{NO}_{3}$. The MCM uses a rate coefficient of $2.4 \times 10^{-17} \mathrm{~cm}^{3} \mathrm{~s}^{-1}$ for the reaction of $\delta$-ICN with $\mathrm{O}_{3}$, which is 5 times faster than the value of $4.4 \times 10^{-18} \mathrm{~cm}^{3} \mathrm{~s}^{-1}$ recommended by W2018, giving a partial lifetime on the order of $12 \mathrm{~h}$ for an $\mathrm{O}_{3}$ mixing ratio of $40 \mathrm{ppb}$. On the other hand, the MCM uses a rate constant for the reaction of $\delta$-ICN with $\mathrm{NO}_{3}$, which is 10 times slower than that recommended by W2018, but even so the lifetime of $\delta$-ICN with respect to the reaction with $\mathrm{NO}_{3}$ as estimated by W2018 is of the order of $4 \mathrm{~d}$, so this loss pathway would have to be much faster to reduce the modelled night-time $\delta$-ICN close to that which was observed.

Of the observed $\delta$-ICN, the two trans (E) isomers have the highest mixing ratios with $\mathrm{E}-\left(1-\mathrm{ONO}_{2}, 4-\mathrm{CO}\right)-\mathrm{ICN}$ being the most abundant (Figs. 8 and S2). Focusing on the last $4 \mathrm{~d}$ (three nights) of the campaign (Fig. 8), when we have most confidence in the data (i.e. when the plastic valve was used; see Sect. 3.2), we see that the observed ICN C1:C4 isomer ratio exhibits a diel cycle with higher values at night (mean of 2.0 and SD of 0.3 ) and an overall mean of 1.4 (SD of 0.6). These values are considerably lower than would 
be expected based solely on the addition of $\mathrm{NO}_{3}$ to isoprene occurring in the $\mathrm{C} 1$ and $\mathrm{C} 4$ positions in a ratio of 6 (C1:C4) (W2018). Our observed ratios are more comparable to the $\mathrm{C} 1: \mathrm{C} 4$ isomer ratio of 2.8 reported in Schwantes et al. (2015) for their environmental chamber, although in their experiment the ICN mostly came from $\mathrm{RO}_{2}+\mathrm{RO}_{2}$ reactions (see Sect. S1.2) because the $\mathrm{NO}$ and $\mathrm{NO}_{3}$ concentrations were low. Turning to the $\mathrm{E}: \mathrm{Z}$ ratios, we observed the E-ICN isomers as dominating over the Z-ICN isomers. The (1-ONO 2 , 4-CO)-ICN isomers exhibit a mean night-time $\mathrm{E}: \mathrm{Z}$ ratio of 8 (SD of 1.4$)$, whilst the $\left(4-\mathrm{ONO}_{2}, 1-\mathrm{CO}\right)-\mathrm{ICN}$ isomers exhibit a mean night-time $\mathrm{E}: \mathrm{Z}$ ratio of 11 (SD of 1.5 ), giving an overall mean night-time $E: Z$ ratio of 9 (SD of 1.0). These values are far greater than the trans: cis ratio of 1 presumed by $\mathrm{W} 2018$ for the reaction of $\mathrm{NO}_{3}$ addition to isoprene based on the $\mathrm{OH}$ addition to $\mathrm{C} 1$ of isoprene calculated by Peeters et al. (2009). However, it should be noted that the peroxy radicals formed from the reaction of the adducts with $\mathrm{O}_{2}$ may be in a different ratio as these reactions are reversible, similar to those for peroxy radicals formed following $\mathrm{OH}$ addition to isoprene.

As noted above, the ratios of C1-ICN to C4-ICN exhibit diel patterns (Fig. 8). The ratios are higher at night and lower in the daytime. The evening ratios are driven by the preferential addition of $\mathrm{NO}_{3}$ to the $\mathrm{C} 1$ position as discussed above. The decrease in this ratio during the morning could be explained if the lifetime of C1-ICN were shorter than for the other isomers. However, the rate coefficients for reaction with $\mathrm{OH}$ recommended by W2018 are about $20 \%$ slower for C1-ICN than for C4-ICN. Photolysis is expected to be the largest daytime sink, but Xiong et al. (2016) only determined this for E-(4-ONO $2,1-\mathrm{CO})-\mathrm{ICN}$.

\subsection{Propanone nitrate}

Figures S6 and 7 show the time series and diel patterns of the measured and modelled propanone nitrate. The observed mixing ratios are generally higher than the modelled values. The chemical lifetime of propanone nitrate is calculated to be around $10 \mathrm{~h}$ during the daytime and considerably longer at night, so transport is expected to play an important role in the distribution of propanone nitrate. The mixing term dominates the modelled lifetime and the resulting mixing ratios are highly dependent on the assumptions regarding this term. As discussed in Sect. 4, the same first-order mixing loss rate is used for all species. As significant concentrations of propanone nitrate are expected to remain in the residual layer, this may lead to an overestimation of the mixing, but reducing this would worsen the comparison with the observed propanone nitrate. Despite these issues, the model can still provide insight into the dominant chemical production processes.

The primary source of propanone nitrate in the model is the $\mathrm{OH}$ oxidation of $\delta$-ICN, which is formed from $\mathrm{NO}_{3}$ oxidation of isoprene. Consequently, the modelled propanone nitrate and $\delta$-ICN time series share many similarities (Fig. S6). As discussed above, the production of $\delta$-ICN and its loss via $\mathrm{OH}$ oxidation occur mostly during the daytime, so this source of propanone nitrate is predominantly during the daytime. On nights when $\mathrm{OH}$ is present even at low concentrations it can be a sizable source due to the relatively large amounts of $\delta$-ICN at night. Propanone nitrate is also formed from oxidation of $\delta$-ICN by $\mathrm{O}_{3}$. This is a relatively small source except on nights when $\mathrm{O}_{3}$ was present (Fig. S1). Propanone nitrate can also be produced following the $\mathrm{NO}_{3}$ addition to propene. Overall, the model results suggest this to be a relatively small source, but that it is often calculated to be the dominant source of some of the nighttime peaks in propanone nitrate.

Both the modelled and observed propanone nitrate reflect the fact that production of propane nitrate can occur both during the daytime and at night (Figs. S6 and 8). Figure 8 shows the temporal variation of the observed propanone nitrate, along with (4-ONO $\left.\mathrm{ONO}_{2}, 1-\mathrm{CO}\right)-\mathrm{ICN}$ for the last $4 \mathrm{~d}$ of the campaign. Propanone nitrate exhibits three peaks: two on the nights of the 19-20 and 20-21 June 2017 and one during the daytime on the 21 June 2017 . These peaks are replicated, but to a lesser extent by the model, which suggests that the peak on the night of the 19-20 June 2017 was OH oxidation of $\delta$-ICN and, to a lesser extent, $\mathrm{NO}_{3}$ addition to propene. The next night $\mathrm{NO}_{3}$ addition to propene was modelled to be the dominant source of the propanone nitrate, with $\mathrm{OH}$ oxidation of $\delta$-ICN being the main source during the following day. The consequence of this pattern in sources is that both the observed and modelled mixing ratios show no clear diel cycle, possibly a weak bimodal pattern in the mean, and large day-to-day variability (Fig. 7).

The modelled propanone nitrate is generally less than the $\delta$-ICN. In contrast, the observed propanone nitrate is typically a lot greater than total $\delta$-ICN. This might in part be due to the model being unable to simulate the mixing correctly, but, as discussed in Sect. 5.2, the model simulates considerably larger amounts of $\delta$-ICN than observed, and getting the wrong balance between the various production and loss terms of the $\delta$-ICN will likely impact the modelled propanone nitrate.

\section{$5.4 \delta$-IHN}

Four $\delta$-IHN can be formed from the $\mathrm{OH}$ addition to isoprene in the $\mathrm{C} 1$ and $\mathrm{C} 4$ positions: $\mathrm{E}-\left(1-\mathrm{OH}, 4-\mathrm{ONO}_{2}\right)-\mathrm{IHN}$, $\left.\mathrm{Z}-\left(1-\mathrm{OH}, 4-\mathrm{ONO}_{2}\right)-\mathrm{IHN}, \mathrm{E}-\left(4-\mathrm{OH}, 1-\mathrm{ONO}_{2}\right)-\mathrm{IHN}\right)$, and Z(4-OH, 1- $\mathrm{ONO}_{2}$ )-IHN) (Fig. 5). The MCM treats the trans and $c i$ s $\delta$-IHN isomers as a single species and thus considers two $\delta$-IHN: (1-OH, 4- $\left.-\mathrm{ONO}_{2}\right)-\mathrm{IHN}$ and (4-OH, 1- $\left.\mathrm{ONO}_{2}\right)-$ IHN. The two modelled $\delta$-IHN are simulated to have very similar mixing ratios during the daytime with peaks values of around 1 ppt (Figs. 9 and S7). Whilst we have previously demonstrated that our system can measure the four $\delta$-IHN (Mills et al., 2016), we found no evidence of them in Beijing 


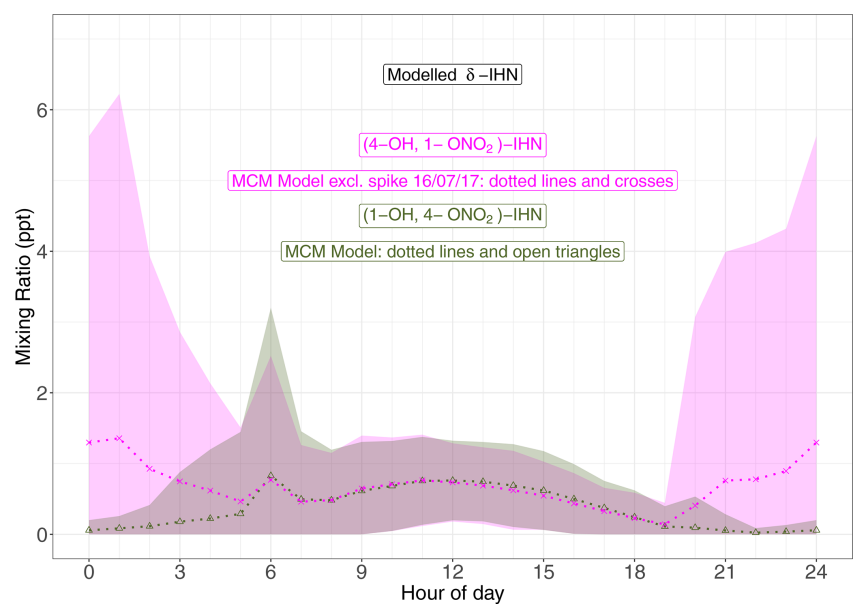

Figure 9. Diel pattern of MCM modelled $\delta$-IHN ((1-OH, 4-ONO 2$)$ IHN and (4-OH, 1- $\left.\left.\mathrm{ONO}_{2}\right)-\mathrm{IHN}\right)$. Data points are the means, and the shaded areas represent $\pm 1 \mathrm{SD}$ in the variability of values for each hour of the day.

despite the modelled daytime mixing ratios being above our detection limit of $0.1 \mathrm{ppt}$.

The model also simulates enhancements of $(4-\mathrm{OH}, 1$ $\mathrm{ONO}_{2}$ )-IHN of around $15-30 \mathrm{ppt}$ on several nights coincident with enhanced mixing ratios of the $\delta$-ICN (Figs. 9 and S7) because (4-OH, 1- $\mathrm{ONO}_{2}$ )-IHN is also formed when the $\mathrm{INO}_{2}$ radicals react with organic peroxy radicals. As discussed in Sect. 5.2, $\mathrm{INO}_{2}$ is mostly produced during the daytime, but on some nights $\mathrm{INO}_{2}$ mixing ratios were simulated to be high, leading to these elevated mixing ratios of both (4$\mathrm{OH}, 1-\mathrm{ONO}_{2}$ )-IHN and $\delta$-ICN. We were only making measurements on a few of the nights when the model simulates these enhancements in $\left(4-\mathrm{OH}, 1-\mathrm{ONO}_{2}\right)-\mathrm{IHN}$, but again we did not detect it, and although we saw small enhancements in $\delta$-ICN, they were far smaller than modelled.

\section{Conclusions}

Following $\mathrm{OH}$ oxidation of isoprene, the concentration of NO is critical in determining the lifetime, fate, and redistribution of the isoprene-derived peroxy radicals, ISOPOO. Measuring IHN, products of the reactions between NO and ISOPOO, provides observational insight into this chemistry. Our measurements show that in the summertime conditions experienced in Beijing the $\beta$-IHN ratio ((1-OH, 2- $\left.\mathrm{ONO}_{2}\right)$ IHN to (4-OH, 3- $\left.\left.\mathrm{ONO}_{2}\right)-\mathrm{IHN}\right)$ increases at $\mathrm{NO}$ mixing ratios below $2 \mathrm{ppb}$, providing observational field evidence of the redistribution of the ISOPOO away from the kinetic ratio towards a new thermodynamic equilibrium consistent with box model calculations.

There are absolute discrepancies between the modelled and observed ratio of $\beta$-IHN, with the observed values being higher. Some of this might be resolved with a more accurate calibration of (1-OH, 2-ONO 2 )-IHN. However, there may be issues with the chemical scheme, and it is noteworthy that the model underestimates the measured $\mathrm{RO}_{2}$ mixing ratios for both those classed as simple and those as complex, the latter which include ISOPOO (Whalley et al., 2021). Whilst an underestimation of the $\beta$-ISOPOO might impact the absolute mixing ratios of modelled $\beta$-IHN, an underestimation of the total $\mathrm{RO}_{2}$ can affect the $\beta$-IHN ratio as the rate constant for the reaction of $\mathrm{RO}_{2}$ with (1-OH, 2-OO)-ISOPOO is slower than that for reaction of $\mathrm{RO}_{2}$ with $(4-\mathrm{OH}, 3-\mathrm{OO})-$ ISOPOO and this contributes to the higher $\beta$-IHN ratios at the lower NO mixing ratios.

The diel pattern in observed $\mathrm{NO}$ (along with $\mathrm{OH}$ and peroxy radicals) in Beijing suggests that the ratio of (1$\left.\mathrm{OH}, 2-\mathrm{ONO}_{2}\right)-\mathrm{IHN}$ to $\left(4-\mathrm{OH}, 3-\mathrm{ONO}_{2}\right)-\mathrm{IHN}$ should have increased during the afternoon, but unfortunately we were unable to make enough measurements to observe this given the day-to-day variability in atmospheric composition. However, our observations demonstrate that more extensive measurements of individual $\beta$-IHN should provide insight into the $\beta$-ISOPOO speciation and how it changes under different chemical regimes.

Like the $\beta$-IHN, $\delta$-IHN are formed following $\mathrm{OH}$ addition to isoprene in the $\mathrm{C} 1$ and $\mathrm{C} 4$ positions, and their rates of production are dependent on the kinetic yields of their respective ISOPOO from $\mathrm{O}_{2}$ reaction with the $\mathrm{C} 1$ and $\mathrm{C} 4$ adducts and redistribution amongst the ISOPOO. The rapid isomerisation of the Z- $\delta$-ISOPOO leads to a greater $\beta: \delta$ ISOPOO ratio than the kinetic one. Whilst the model strongly favours production of $\beta$-IHN over the $\delta$-IHN, it still suggests that there should be enough $\delta$-IHN present during the daytime for us to detect with our measurement system. However, we found no evidence of their presence, which may suggest that the model underestimates the $\beta: \delta$ ISOPOO ratio or the $\delta$-IHN losses.

The observed amounts of $\delta$-ICN demonstrate the importance of daytime addition of $\mathrm{NO}_{3}$ to isoprene in Beijing. Hamilton et al. (2021) have also shown this source of organic nitrates to be important for the formation secondary organic aerosol in Beijing. We did, however, observe far less $\delta$-ICN than we modelled, which may suggest that the predominant source of the $\delta$-ICN in the model (reaction of NO with $\delta$ nitrooxy peroxy radicals) is too large or that the sink is too small. The main source of propanone nitrate in the model is the $\mathrm{OH}$ oxidation of $\delta$-ICN, so the atmospheric budgets of these two nitrates are linked. Observations of propanone nitrate suggest it can be a marker of this chemistry, although other sources, such as the $\mathrm{NO}_{3}$ addition to propene and the transport of propane nitrate, need to be taken into consideration. The model suggests that reaction of the $\delta$-nitrooxy peroxy radicals with organic peroxy radicals is a significant source of (4-OH, 1-ONO $\mathrm{ON}_{2}$-IHN at night, but this is not supported by our observations.

Our speciated measurements of the four $\delta$-ICN isomers provide insight into the isomeric distribution of the $\delta$ nitrooxy peroxy radicals. The two trans $\delta$-ICN isomers are 
observed to have the highest mixing ratios, with $\mathrm{E}-\left(1-\mathrm{ONO}_{2}\right.$, 4-CO)-ICN being the most abundant. However, the mean $\mathrm{C} 1$ : $\mathrm{C} 4$ isomer ratio is 1.4 , which is considerably lower than would be expected based solely on the addition of $\mathrm{NO}_{3}$ to isoprene occurring in the $\mathrm{C} 1$ and $\mathrm{C} 4$ positions in a $6: 1$ ratio. This raises the question as to whether it is appropriate to represent the $\delta$-ICN by a single $\mathrm{C} 1$ nitrated isomer, as has been done in the MCM. We observed the trans-ICN isomers to dominate over the cis-ICN isomers with a mean ratio of 7 , far greater than the trans: cis ratio of 1 presumed by W2018 for the reaction of $\mathrm{NO}_{3}$ addition to isoprene. This suggests that thermodynamic redistribution of the $\delta$-nitrooxy peroxy radicals may also be important.

This study demonstrates the value of speciated IN measurements in testing the understanding of isoprene degradation chemistry, and more measurements would provide more robust constraints. One reason for the limited data was the need for a different instrument setup for the measurement of $\left(1-\mathrm{OH}, 2-\mathrm{ONO}_{2}\right)-\mathrm{IHN}$. Resolving this would increase data capture and provide concurrent measurements of a range of speciated IN that can be used to test different aspects of the isoprene degradation system simultaneously, including the balance between $\mathrm{OH}$ and $\mathrm{NO}_{3}$ oxidation of isoprene. Observations of speciated IN in a wide range of NO / VOC chemical space at different times of day would provide greater constraint on their chemistry, in particular the isomeric distribution and fate of the peroxy radicals. The chemistry of the isoprene degradation chemistry is complex, involving multiple species and reactions. Analysis of field measurements of IN can help constrain aspects of this, but interpretation would be enhanced by simultaneous measurements of other chemical species (e.g. other products of the nitrooxy peroxy radicals), as well as improved quantification of several reaction rate constants. Further laboratory studies are required to improve quantification of the IN lifetimes, in particular with respect to photolysis of the ICN, deposition, and hydrolysis, and to better constrain the peroxy radical reactions, including the branching ratio of the NO reaction that leads to IHN.

Code availability. The MCM code is available from the authors on request.

Data availability. The observational data and diel cycles from the MCM in the figures are provided in the Supplement. The $15 \mathrm{~min}$ data from the MCM are available from the authors on request.

Supplement. The supplement related to this article is available online at: https://doi.org/10.5194/acp-21-6315-2021-supplement.

Author contributions. CER led the data interpretation and writing of the manuscript. GPM made the measurements of the IN with the assistance of YL. LKW did the MCM modelling. CER, WJB, SG, $\mathrm{DEH}, \mathrm{CNH}$, RLJ, JDL, XW, and CY were involved in the project planning and leading the measurement groups. WJFA, LRC, JRH, SK, LJK, BO, ES, FS, and RWM provided measurement data. All authors commented on the manuscript.

Competing interests. The authors declare that they have no conflict of interest.

Special issue statement. This article is part of the special issue "In-depth study of air pollution sources and processes within Beijing and its surrounding region (APHH-Beijing) (ACP/AMT interjournal SI)". It is not associated with a conference.

Acknowledgements. We are grateful for funding provided by the UK Natural Environment Research Council (NERC), UK Medical Research Council, and the Natural Science Foundation of China (NSFC) under the framework of the Newton Innovation Fund. Eloise Slater and Robert Woodward-Massey are grateful to the NERC SPHERES Doctoral Training Programme for funding their PhD studentships. Claire E. Reeves acknowledges Andrew Rickard (NCAS, University of York) for providing information on the MCM.

Financial support. This research has been supported by the UK Natural Environment Research Council (NERC; grant nos. NE/N006909/1, NE/N006895/1, NE/N006976/1, and NE/N00700X/1), UK Medical Research Council, the Natural Science Foundation of China (NSFC) under the framework of the Newton Innovation Fund (grant no. 41571130031) and the NERC SPHERES Doctoral Training Programme.

Review statement. This paper was edited by Frank Keutsch and reviewed by three anonymous referees.

\section{References}

Bates, K. H. and Jacob, D. J.: A new model mechanism for atmospheric oxidation of isoprene: global effects on oxidants, nitrogen oxides, organic products, and secondary organic aerosol, Atmos. Chem. Phys., 19, 9613-9640, https://doi.org/10.5194/acp19-9613-2019, 2019.

Bew, S. P., Hiatt-Gipson, G. D., Mills, G. P., and Reeves, C. E.: Efficient syntheses of climate impacting isoprene nitrates and (1R,5S)-(-)-myrtenol nitrate, Beilstein J. Org. Chem., 12, 10811095, https://doi.org/10.3762/bjoc.12.103, 2016.

Emmerson, K. M. and Evans, M. J.: Comparison of tropospheric gas-phase chemistry schemes for use within global models, Atmos. Chem. Phys., 9, 1831-1845, https://doi.org/10.5194/acp-91831-2009, 2009.

Fiore, A. M., Horowitz, L. W., Purves, D. W., Levy II, H., Evans, M. J., Wang, Y., Li, Q., and Yantosca, R. M.: Evaluating the contri- 
bution of changes in isoprene emissions to surface ozone trends over the eastern United States, J. Geophys. Res., 110, D12303, https://doi.org/10.1029/2004JD005485, 2005.

Guenther, A. B., Jiang, X., Heald, C. L., Sakulyanontvittaya, T., Duhl, T., Emmons, L. K., and Wang, X.: The Model of Emissions of Gases and Aerosols from Nature version 2.1 (MEGAN2.1): an extended and updated framework for modeling biogenic emissions, Geosci. Model Dev., 5, 1471-1492, https://doi.org/10.5194/gmd-5-1471-2012, 2012.

Hamilton, J. F., Bryant, D. J., Edwards, P. E., Quyang, B., Bannan, T. J., Mehra, A., Mayhew, A. W., Hopkins, J. R., Dunmore, R. E., Squires, F. A., Lee, J. D., Newland, M. J., Worrall, S. D., Bacak, A., Coe, H., Percival, C., Whalley, L. K., Heard, D. E., Slater, E. J., Jones, R. L., Cui, T., Surratt, J. D., Reeves, C. E., Mills, G. P., Grimmond, S., Sun, Y., Xu, W., Shi, Z., and Rickard, A. R.: Key Role of $\mathrm{NO}_{3}$ Radicals in the Production of Isoprene Nitrates and Nitrooxyorganosulfates in Beijing, Environ. Sci. Technol., 55, 842-853, doi.org/10.1021/acs.est.0c05689, 2021.

Jacobs, M. I., Burke, W. J., and Elrod, M. J.: Kinetics of the reactions of isoprene-derived hydroxynitrates: gas phase epoxide formation and solution phase hydrolysis, Atmos. Chem. Phys., 14, 8933-8946, https://doi.org/10.5194/acp-14-8933-2014, 2014.

Jenkin, M. E., Young, J. C., and Rickard, A. R.: The MCM v3.3.1 degradation scheme for isoprene, Atmos. Chem. Phys., 15, 11433-11459, https://doi.org/10.5194/acp-15-11433-2015, 2015.

Lee, L., Teng, A. P., Wennberg, P. O., Crounse, J. D., and Cohen, R. C.: On Rates and Mechanisms of $\mathrm{OH}$ and $\mathrm{O}_{3}$ Reactions with Isoprene Derived Hydroxy Nitrates, J. Phys. Chem., 118, 16221637, https://doi.org/10.1021/jp4107603, 2014.

Li, J., Mao, J., Min, K.-E., Washenfelder, R. A., Brown, S. S., Kaiser, J., Keutsch, F. N., Volkamer, R., Wolfe, G. M., Hanisco, T. F., Pollack, I. B., Ryerson, T. B., Graus, M., Gilman, J. B., Lerner, B. M., Warneke, C., de Gouw, J. A., Middlebrook, A. M., Liao, J., Welt, A., Henderson, B. H., McNeill, V. F., Hall, S. R., Ullmann, K., Donner, L. J., Paulot, F., and Horowitz, L. W.: Observational constraints on glyoxal production from isoprene oxidation and its contribution to organic aerosol over the Southeast United States, J. Geophys. Res.-Atmos., 121, 9849-9861, https://doi.org/10.1002/2016JD025331, 2016.

Lockwood, A. L., Shepson, P. B., Fiddler, M. N., and Alaghmand, M.: Isoprene nitrates: preparation, separation, identification, yields, and atmospheric chemistry, Atmos. Chem. Phys., 10, 6169-6178, https://doi.org/10.5194/acp-10-6169-2010, 2010.

Mills, G. P., Hiatt-Gipson, G. D., Bew, S. P., and Reeves, C. E.: Measurement of isoprene nitrates by GCMS, Atmos. Meas. Tech., 9, 4533-4545, https://doi.org/10.5194/amt-9-4533-2016, 2016.

Müller, J.-F., Peeters, J., and Stavrakou, T.: Fast photolysis of carbonyl nitrates from isoprene, Atmos. Chem. Phys., 14, 24972508, https://doi.org/10.5194/acp-14-2497-2014, 2014.

Newland, M. J., Bryant, D. J., Dunmore, R. E., Bannan, T. J., Acton, W. J. F., Langford, B., Hopkins, J. R., Squires, F. A., Dixon, W., Drysdale, W. S., Ivatt, P. D., Evans, M. J., Edwards, P. M., Whalley, L. K., Heard, D. E., Slater, E. J., Woodward-Massey, R., Ye, C., Mehra, A., Worrall, S. D., Bacak, A., Coe, H., Percival, C. J., Hewitt, C. N., Lee, J. D., Cui, T., Surratt, J. D., Wang, X., Lewis, A. C., Rickard, A. R., and Hamilton, J. F.: Low$\mathrm{NO}$ atmospheric oxidation pathways in a polluted megacity, At- mos. Chem. Phys., 21, 1613-1625, https://doi.org/10.5194/acp21-1613-2021, 2021.

Nguyen, T. B., Crounse, J. D., Schwantes, R. H., Teng, A. P., Bates, K. H., Zhang, X., St. Clair, J. M., Brune, W. H., Tyndall, G. S., Keutsch, F. N., Seinfeld, J. H., and Wennberg, P. O.: Overview of the Focused Isoprene eXperiment at the California Institute of Technology (FIXCIT): mechanistic chamber studies on the oxidation of biogenic compounds, Atmos. Chem. Phys., 14, 1353113549, https://doi.org/10.5194/acp-14-13531-2014, 2014.

Nguyen, T. B., Crounse, J. D., Teng, A. P., St Clair, J. M., Paulot, F., Wolfe, G. M., and Wennberg, P. O.: Rapid deposition of oxidized biogenic compounds to a temperate forest, P. Natl. Acad. Sci. USA, 112, E392-E401, https://doi.org/10.1073/pnas.1418702112, 2015.

Peeters, J., Nguyen, T. L., and Vereecken, L.: $\mathrm{HO}_{x}$ radical regeneration in the oxidation of isoprene, Phys. Chem. Chem. Phys., 28, 5935-5939, 2009.

Saunders, S. M., Jenkin, M. E., Derwent, R. G., and Pilling, M. J.: Protocol for the development of the Master Chemical Mechanism, MCM v3 (Part A): tropospheric degradation of nonaromatic volatile organic compounds, Atmos. Chem. Phys., 3, 161-180, https://doi.org/10.5194/acp-3-161-2003, 2003.

Schwantes, R. H., Teng, A. P., Nguyen, T. B., Coggon, M. M., Crounse, J. D., St Clair, J. M., Zhang, X., Schilling, K. A., Seinfeld, J. H., and Wennberg, P. O.: Isoprene $\mathrm{NO}_{3}$ Oxidation Products from the $\mathrm{RO}_{2}+\mathrm{HO}_{2}$ Pathway, J. Phys. Chem., 119, 10158 10171, https://doi.org/10.1021/acs.jpca.5b06355, 2015.

Schwantes, R. H., Emmons, L. K., Orlando, J. J., Barth, M. C., Tyndall, G. S., Hall, S. R., Ullmann, K., St. Clair, J. M., Blake, D. R., Wisthaler, A., and Bui, T. P. V.: Comprehensive isoprene and terpene gas-phase chemistry improves simulated surface ozone in the southeastern US, Atmos. Chem. Phys., 20, 3739-3776, https://doi.org/10.5194/acp-20-3739-2020, 2020.

Shi, Z., Vu, T., Kotthaus, S., Harrison, R. M., Grimmond, S., Yue, S., Zhu, T., Lee, J., Han, Y., Demuzere, M., Dunmore, R. E., Ren, L., Liu, D., Wang, Y., Wild, O., Allan, J., Acton, W. J., Barlow, J., Barratt, B., Beddows, D., Bloss, W. J., Calzolai, G., Carruthers, D., Carslaw, D. C., Chan, Q., Chatzidiakou, L., Chen, Y., Crilley, L., Coe, H., Dai, T., Doherty, R., Duan, F., Fu, P., Ge, B., Ge, M., Guan, D., Hamilton, J. F., He, K., Heal, M., Heard, D., Hewitt, C. N., Hollaway, M., Hu, M., Ji, D., Jiang, X., Jones, R., Kalberer, M., Kelly, F. J., Kramer, L., Langford, B., Lin, C., Lewis, A. C., Li, J., Li, W., Liu, H., Liu, J., Loh, M., Lu, K., Lucarelli, F., Mann, G., McFiggans, G., Miller, M. R., Mills, G., Monk, P., Nemitz, E., O’Connor, F., Ouyang, B., Palmer, P. I., Percival, C., Popoola, O., Reeves, C., Rickard, A. R., Shao, L., Shi, G., Spracklen, D., Stevenson, D., Sun, Y., Sun, Z., Tao, S., Tong, S., Wang, Q., Wang, W., Wang, X., Wang, X., Wang, Z., Wei, L., Whalley, L., Wu, X., Wu, Z., Xie, P., Yang, F., Zhang, Q., Zhang, Y., Zhang, Y., and Zheng, M.: Introduction to the special issue "In-depth study of air pollution sources and processes within Beijing and its surrounding region (APHH-Beijing)", Atmos. Chem. Phys., 19, 7519-7546, https://doi.org/10.5194/acp19-7519-2019, 2019.

Squire, O. J., Archibald, A. T., Griffiths, P. T., Jenkin, M. E., Smith, D., and Pyle, J. A.: Influence of isoprene chemical mechanism on modelled changes in tropospheric ozone due to climate and land use over the 21st century, Atmos. Chem. Phys., 15, 5123-5143, https://doi.org/10.5194/acp-15-5123-2015, 2015. 
Teng, A. P., Crounse, J. D., and Wennberg, P. O.: Isoprene Peroxy Radical Dynamics, J. Am. Che. Soc., 139, 5367-5377, https://doi.org/10.1021/jacs.6b12838, 2017.

Vasquez, K. T., Allen, H. M., Crounse, J. D., Praske, E., Xu, L., Noelscher, A. C., and Wennberg, P. O.: Low-pressure gas chromatography with chemical ionization mass spectrometry for quantification of multifunctional organic compounds in the atmosphere, Atmos. Meas. Tech., 11, 6815-6832, https://doi.org/10.5194/amt-11-6815-2018, 2018.

Volkamer, R., San Martini, F., Molina, L. T., Salcedo, D. Jimenez, J. L., and Molina, M. J.: A missing sink for gas-phase glyoxal in Mexico City: Formation of secondary organic aerosol, Geophys. Res. Letts., 34, L19807, https://doi.org/10.1029/2007GL030752, 2007.

von Kuhlmann, R., Lawrence, M. G., Pöschl, U., and Crutzen, P. J.: Sensitivities in global scale modeling of isoprene, Atmos. Chem. Phys., 4, 1-17, https://doi.org/10.5194/acp-4-1-2004, 2004.

Washenfelder, R. A., Young, C. J., Brown, S. S., Angevine, W. M. Atlas, E. L., Blake, D, R., Bon, D. M., Cubison, M. J., de Gouw, J. A., Dusanter, S., Flynn, J., Gilman, J. B., Graus, M., Griffith, S., Grossberg, N., Hayes, P. L., Jimenez, J. L., Kuster, W. C., Lefer, B. L. Pollack, I. B., Ryerson, T. B., Stark, H., Stevens, P. S., and Trainer, M. K: The glyoxal budget and its contribution to organic aerosol for Los Angeles, California, during CalNex 2010, J. Geophys. Res., 116, D00V02, https://doi.org/10.1029/2011JD016314, 2011.

Wennberg, P. O., Bates, K. H., Crounse, J. D., Dodson, L. G., McVay, R. C., Mertens, L. A., Nguyen, T. B., Praske, E., Schwantes, R. H., Smarte, M. D., St Clair, J. M., Teng, A. P., Zhang, X., and Seinfeld, J. H.: Gas-Phase Reactions of Isoprene and Its Major Oxidation Products, Chem. Rev., 118, 3337-3390, https://doi.org/10.1021/acs.chemrev.7b00439, 2018.
Whalley, L. K., Slater, E. J., Woodward-Massey, R., Ye, C., Lee, J. D., Squires, F., Hopkins, J. R., Dunmore, R. E., Shaw, M., Hamilton, J. F., Lewis, A. C., Mehra, A., Worrall, S. D., Bacak, A., Bannan, T. J., Coe, H., Percival, C. J., Ouyang, B., Jones, R. L., Crilley, L. R., Kramer, L. J., Bloss, W. J., Vu, T., Kotthaus, S., Grimmond, S., Sun, Y., Xu, W., Yue, S., Ren, L., Acton, W. J. F., Hewitt, C. N., Wang, X., Fu, P., and Heard, D. E.: Evaluating the sensitivity of radical chemistry and ozone formation to ambient VOCs and $\mathrm{NO}_{x}$ in Beijing, Atmos. Chem. Phys., 21, 2125-2147, https://doi.org/10.5194/acp-21-2125-2021, 2021.

Wu, S., Mickley, L. J., Jacob, D. J., Logan, J. A. Yantosca, R. M., and Rind, D.: Why are there large differences between models in global budgets of tropospheric ozone?, J. Geophys. Res., 112, D05302, https://doi.org/10.1029/2006JD007801, 2007.

Xiong, F., McAvey, K. M., Pratt, K. A., Groff, C. J., Hostetler, M. A., Lipton, M. A., Starn, T. K., Seeley, J. V., Bertman, S. B., Teng, A. P., Crounse, J. D., Nguyen, T. B., Wennberg, P. O., Misztal, P. K., Goldstein, A. H., Guenther, A. B., Koss, A. R., Olson, K. F., de Gouw, J. A., Baumann, K., Edgerton, E. S., Feiner, P. A., Zhang, L., Miller, D. O., Brune, W. H., and Shepson, P. B.: Observation of isoprene hydroxynitrates in the southeastern United States and implications for the fate of $\mathrm{NO}_{x}$, Atmos. Chem. Phys., 15, 11257-11272, https://doi.org/10.5194/acp-1511257-2015, 2015.

Xiong, F., Borca, C. H., Slipchenko, L. V., and Shepson, P. B.: Photochemical degradation of isoprene-derived 4,1-nitrooxy enal, Atmos. Chem. Phys., 16, 5595-5610, https://doi.org/10.5194/acp-16-5595-2016, 2016. 